Historic, Archive Document

Do not assume content reflects current scientific knowledge, policies, or practices. 

LIBEARY IMCOANTINO

- APR 301929

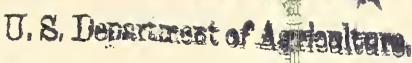

AUGUSTA NURSERIES

N. L. Shreckhise, Mgr.

MOUNT SIDNEY, VIRGINIA

Phone thru Weyers Cave, 23-F-12

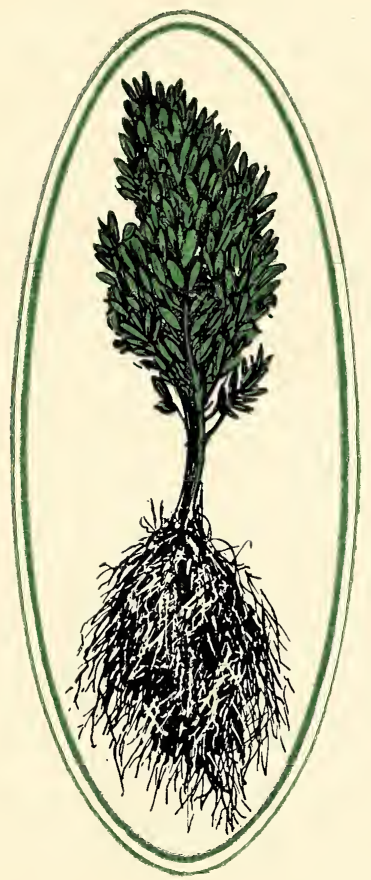

Catalogue of

Shade Trees, Evergreens E Shrubbery

MEMBER OF

4 American Association ${ }^{\circ}$ Nurseryment? 


\section{LOCATION OF NURSERY}

Two miles East of Mount Sidney, Virginia, just off of the Valley Pike, in the famous Shenandoah Valley.

References: Our customers, the residences of some of whom are shown in this catalogue, which also shows the plantings we made, which will give you an idea of the character of our goods and the kind of service we render.

We cater to the distinct and critical clientele that wants plants which will grow and be effective immediately.

Territory is limited to the Valley, delivery being made by truck day after digging, therebv getting perfectly fresh plants that will grow.

Terms and conditions of sale will be made according to service wanted.

We deliver at Nursery, or by truck at any point, or make plantings.

Prices will be found on last pages. 
A U GUSTA N URSERIES

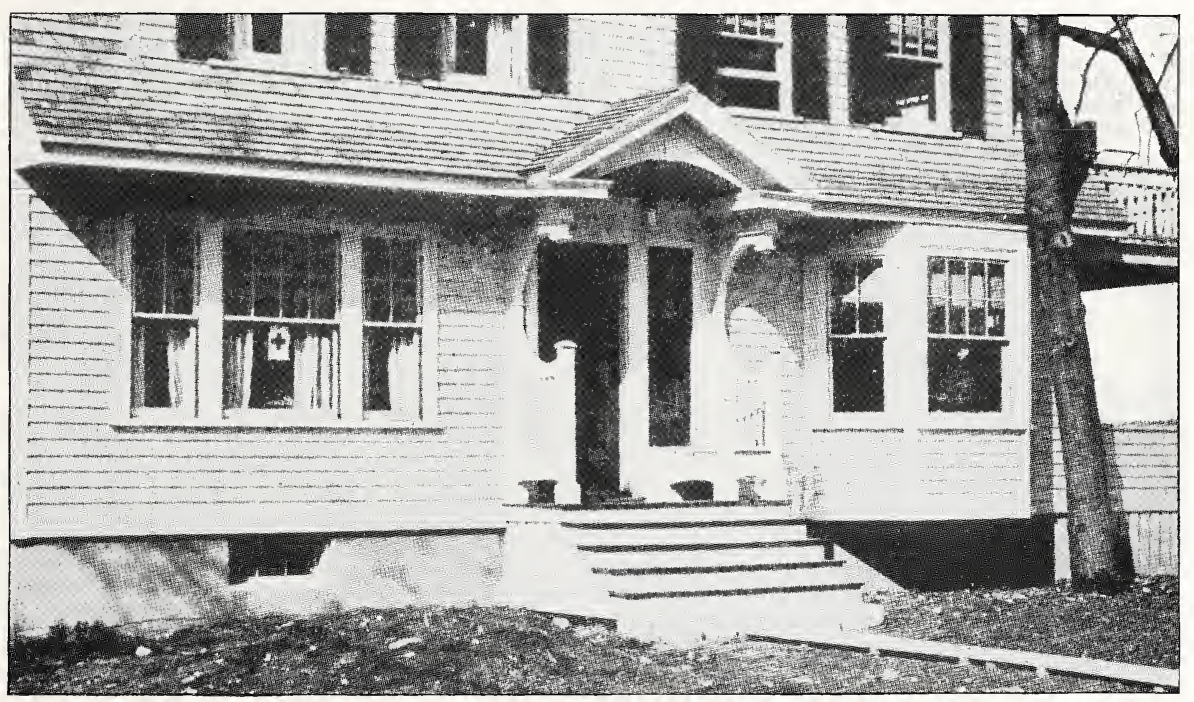

BEFORE

If your house is as bare as this, and you want it to look as this one did after planting (see below) just take advantage of this catalogue.

Note the striking and pleasing contrast.

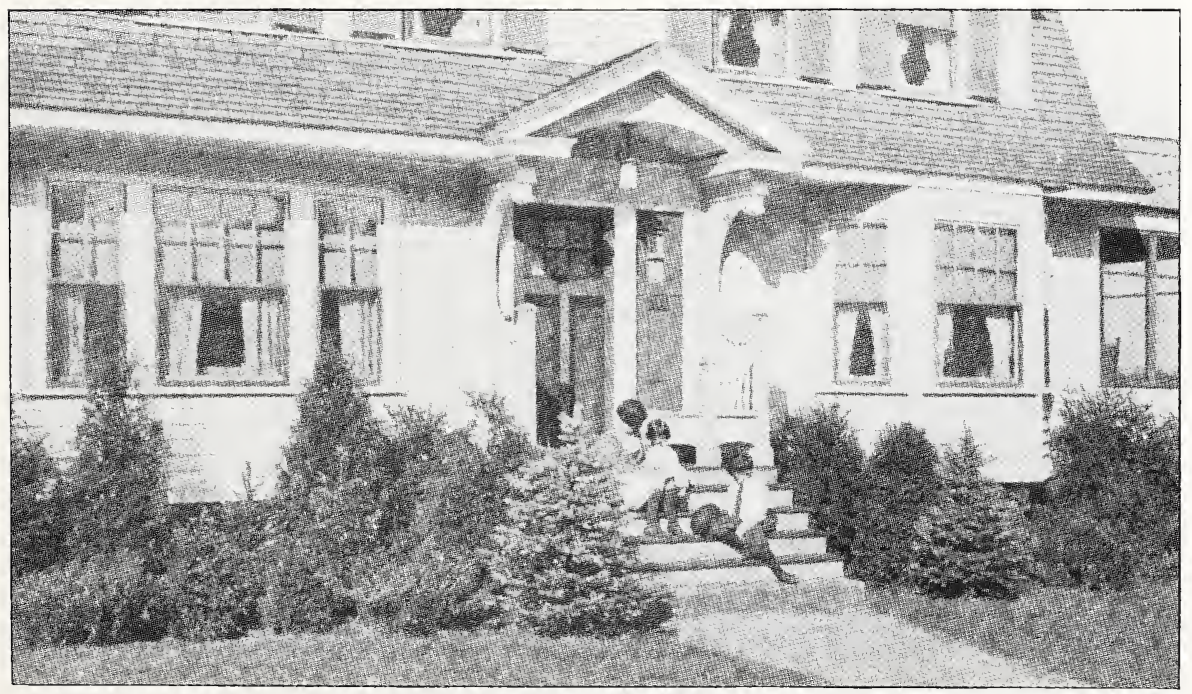

AFTER

This collection of beautiful evergreens and flowering plants will decorate a fifty-foot front similar to that in this picture. 
A U G USTA N.URSERIES

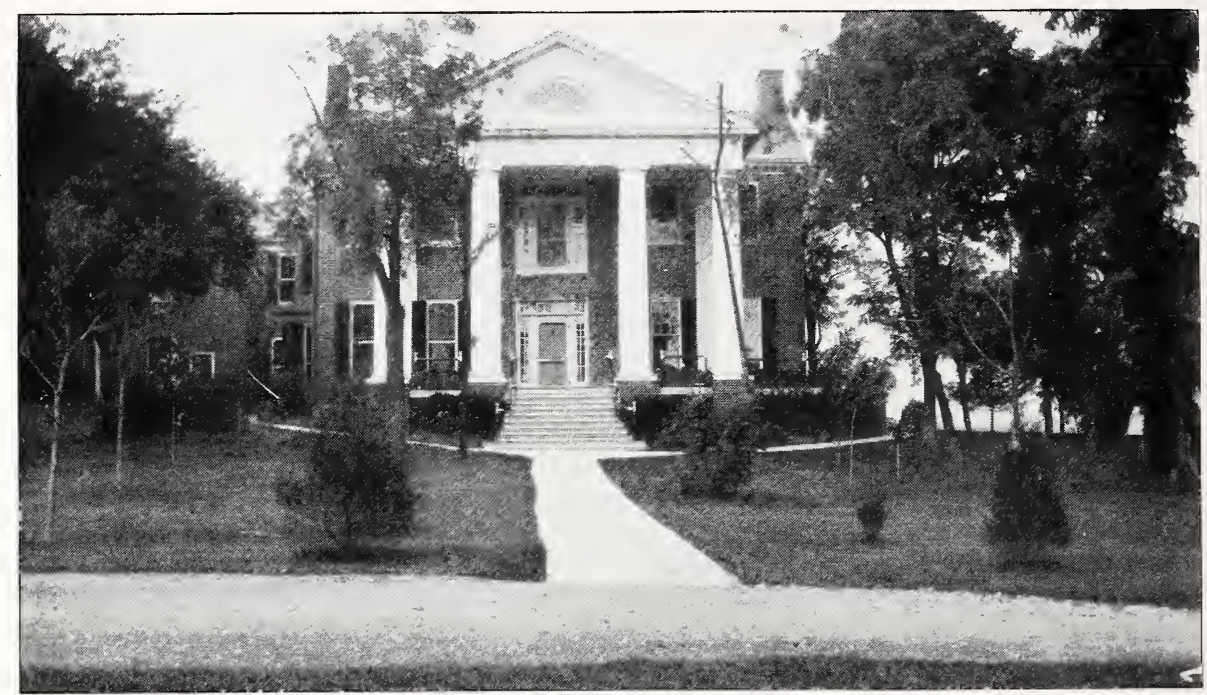

Court Manor, residence of Mr. W. Starke Kilmer, New Market, Va. A large grouping of evergreens and shrubs was planted in foreground since this photo was taken.

Mr. Kilmer spent $\$ 15,000.00$ in ornamentation of this farm, the plants for which we furnished. It required fifty varieties of plants, totalling several thousands, less than one percent of which failed to grow. We specially refer to Mr. Kilmer as to quality and service at his business address, Binghampton, N. Y.

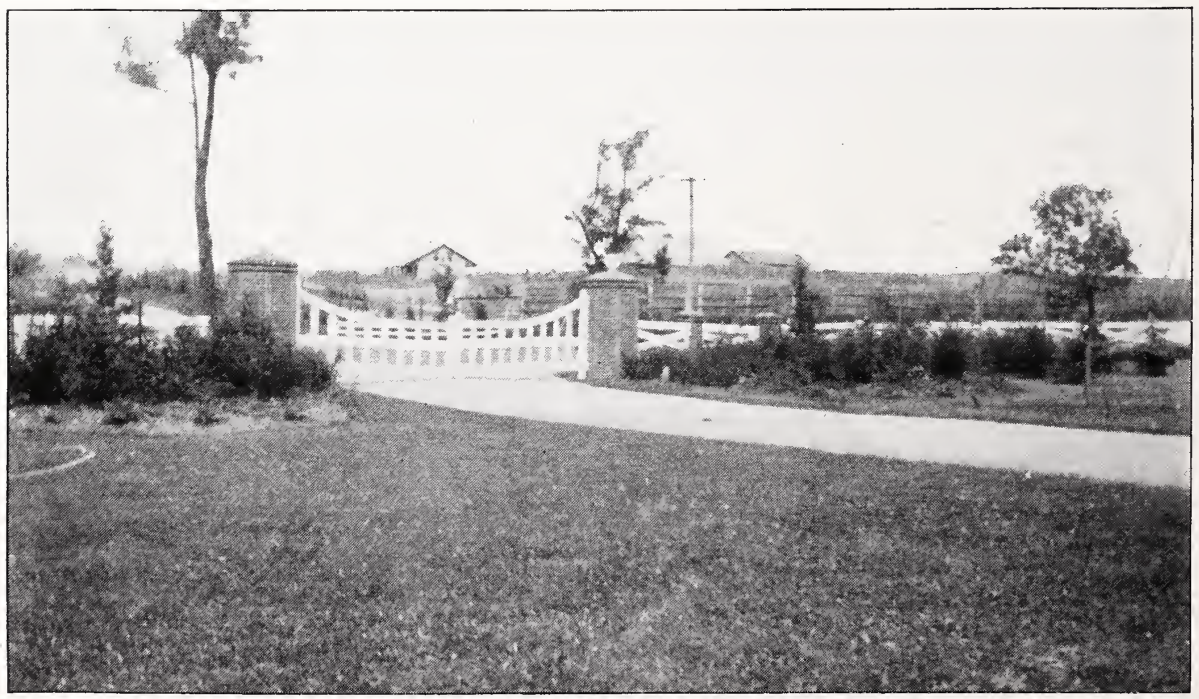

Inside Entrance to Court Manor 


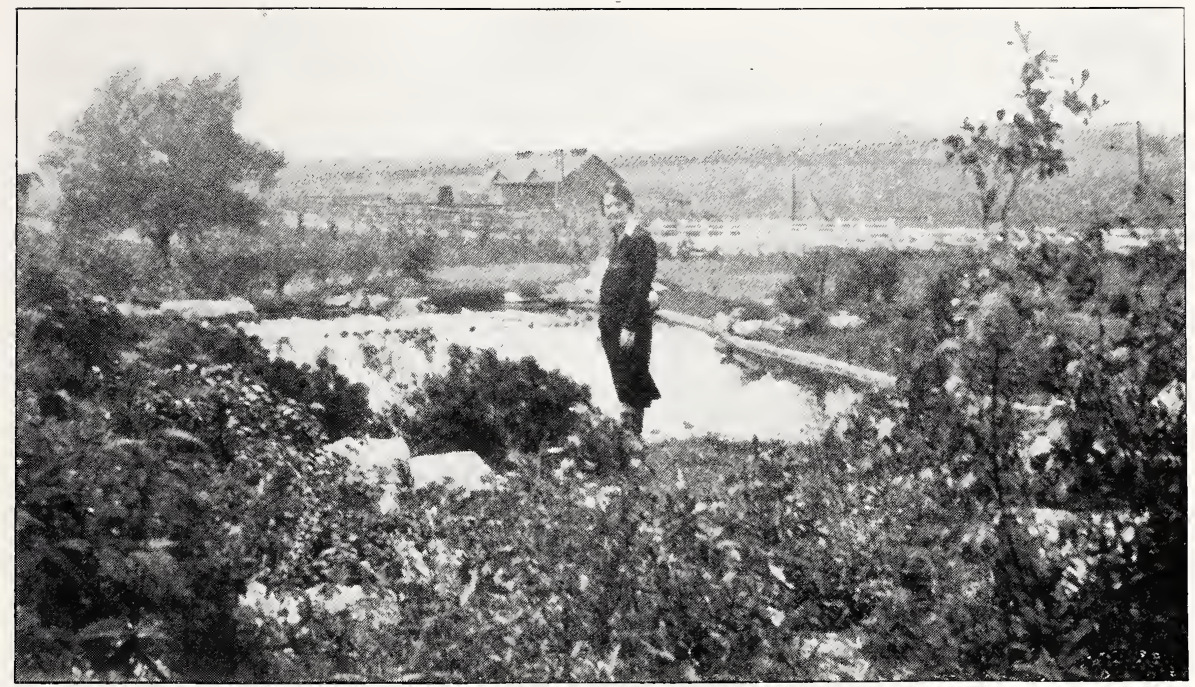

Photograph of Trout Pool in the Beautiful Lawn of Court Manor

This pool is built in solid rock, with falls at entrance and falls at exit, surrounded with plants of Kalmia Latifolia, Azaleas, Rhododendrons, different varieties of evergreens, flowering shrubs and ferns, making it look just like nature itself had formed it. The pool contains a large number of brook and rainbow trout.

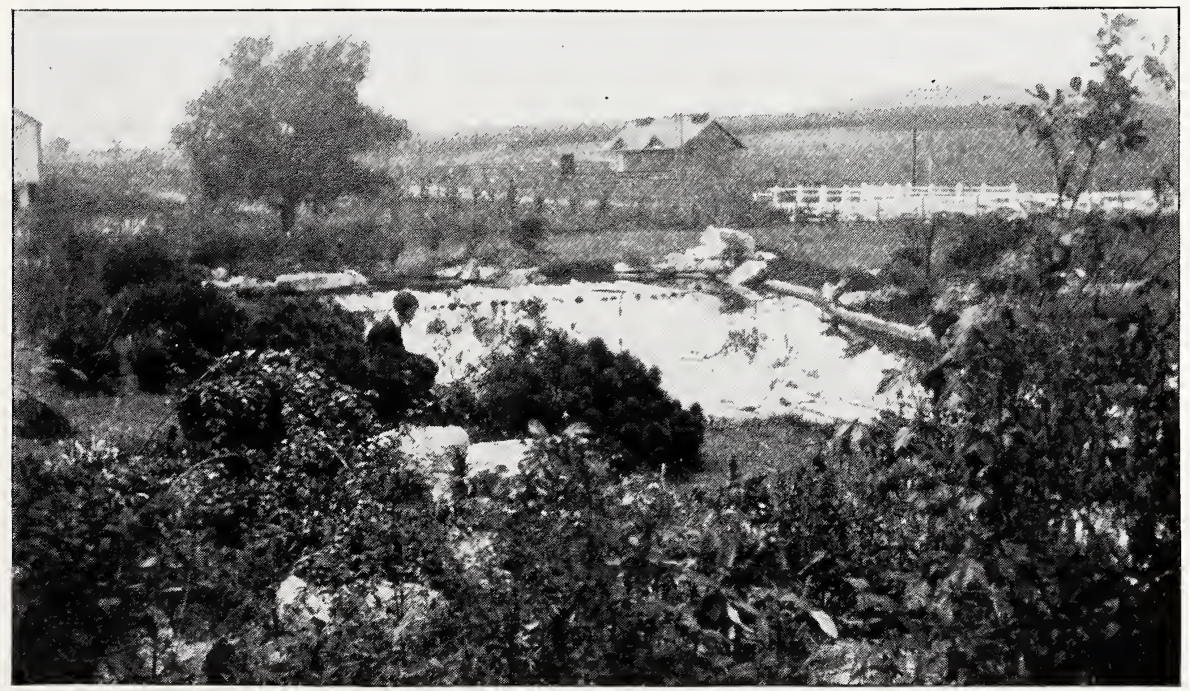

Another Photo of the Same Pool 


\section{EVERGREENS}

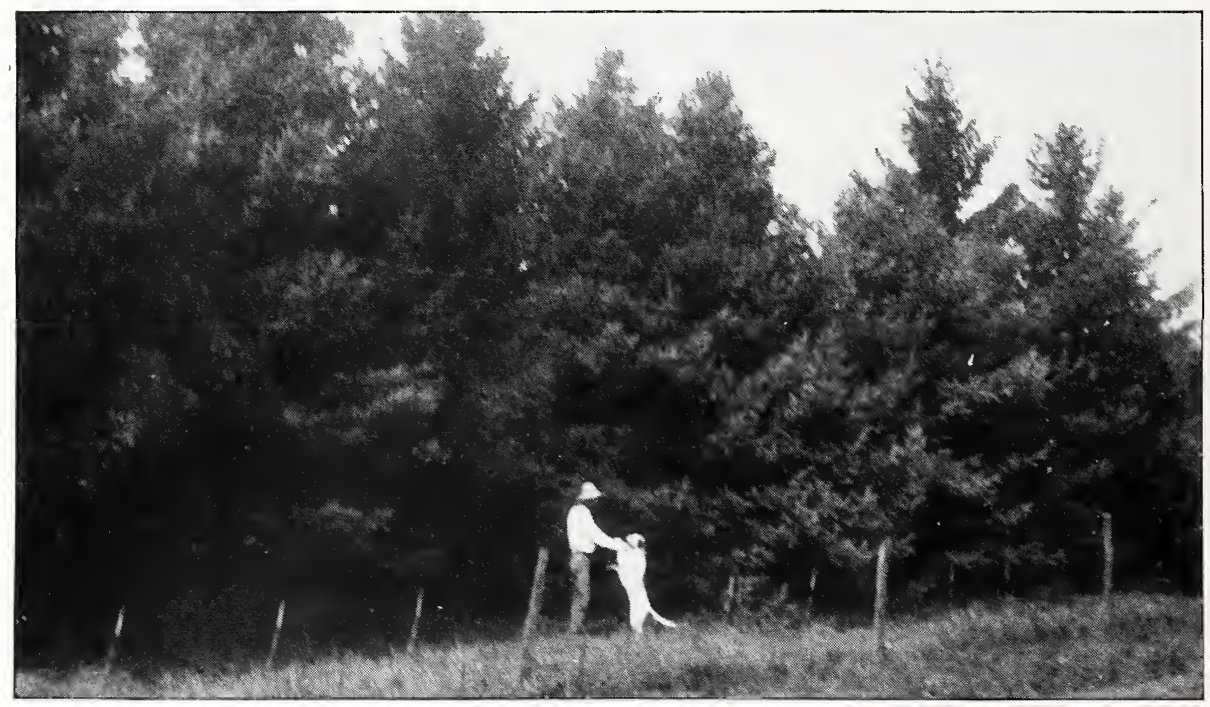

Evergreens-a thing of beauty and perpetual joy. Not only brightening up a landscape in Summer, but making things green in Winter, typifying Spring and things to come; making an ornamentation and giving protection to everything else in its contact. It is graceful in form, restful in color, inspiring in presence, and of lasting influence, because of its great and noble character.

We submit the varieties on the following pages as being a part of what we grow.

We aim to grow the best suited varieties for our local territory.

Note:-Evergreens need plenty of moisture and more moisture, first year especially. 


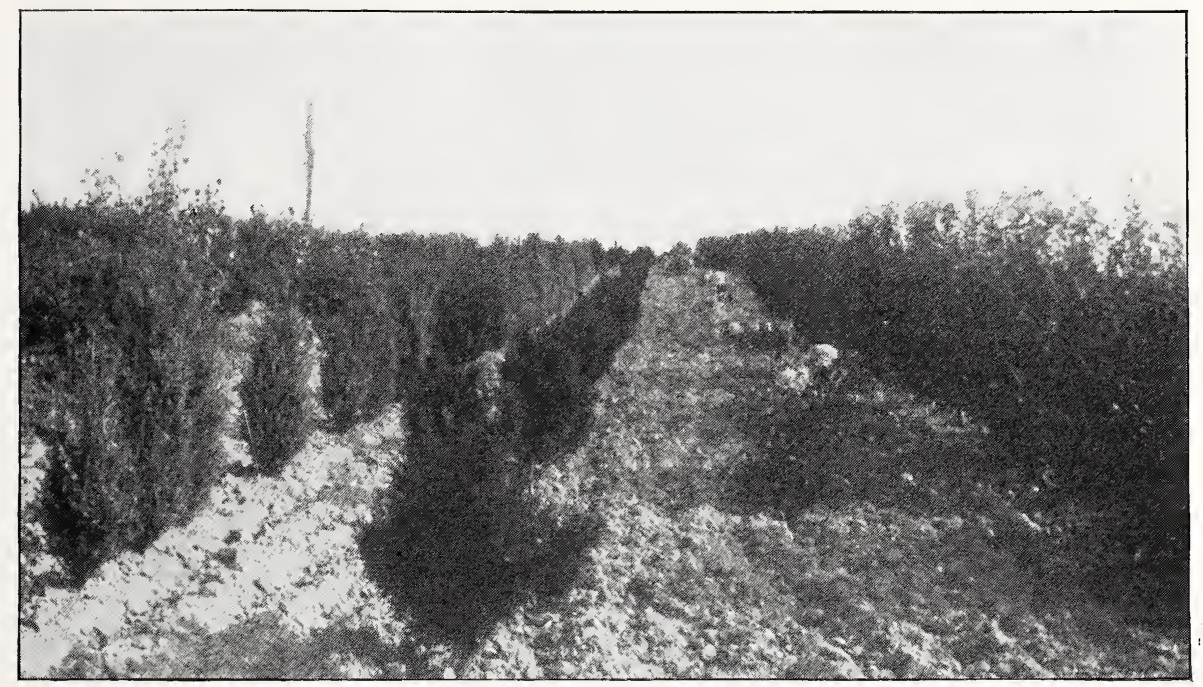

Photo of Retinosporas and Irish Juniper, taken in Nursery August 1, 1925

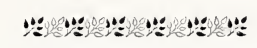

\section{WHY AN EVERGREEN}

\section{And Why Plant a Properly Nursery Grown Evergreen Instead of a Seedling from the Forest}

An Evergreen is grown from either a seedling or from a cutting of any particular variety, in beds one to two years, then transplanted to Nursery rows, after root pruning, then transplanted two to four times in as many years, each time root pruned to get the dense and compact root system, thereby hardening the plant, getting it ready for planting in lawn, now being from six to ten years old.

Some varieties are grafted to get its particular shape or peculiar color. 


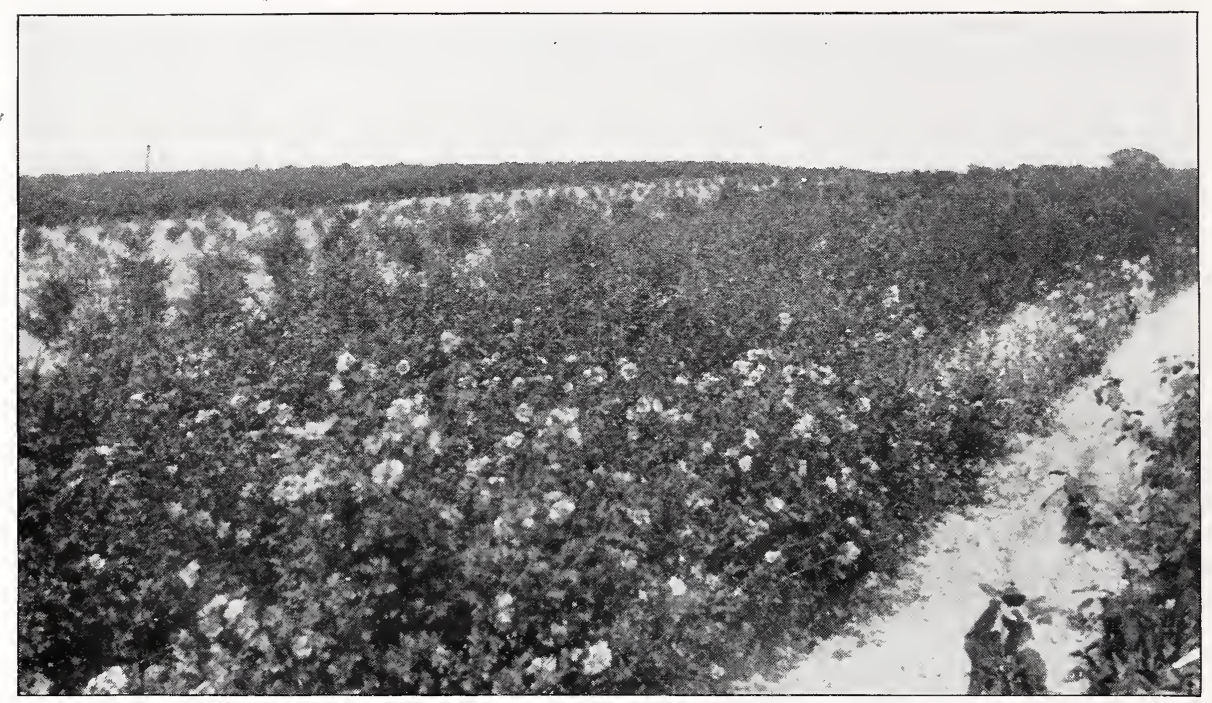

Photo in Nursery of Altheas and Persian Lilacs

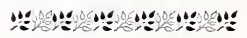

\section{CARE FOR EVERGREENS}

When an Evergreen is dug in Nursery, it is balled and burlapped, or wrapped in heary corrugated paper over roots.

When received, should be immediately planted in extra large holes, with only good soil. well tamped.

The only artificial fertilizer which should be used in the holes is Raw Bone Meal-can't use too much, and any wellrotted stable manure around the plant on top of ground.

Leaf mold or woods earth is an excellent plant food to put in the holes for Evergreens, thereby giving it its natural food when it is in its natural habitat.

Evergreens have their enemies: First, worm that lives in a sack and eats foliage-destror these bags in early Summer: Second, pine rust caused by a red spider; Third, the other trouble is the dog. Canines and Conifers don t mix-either tie up the pup or screen with wire, or else plant something in front for protection. 


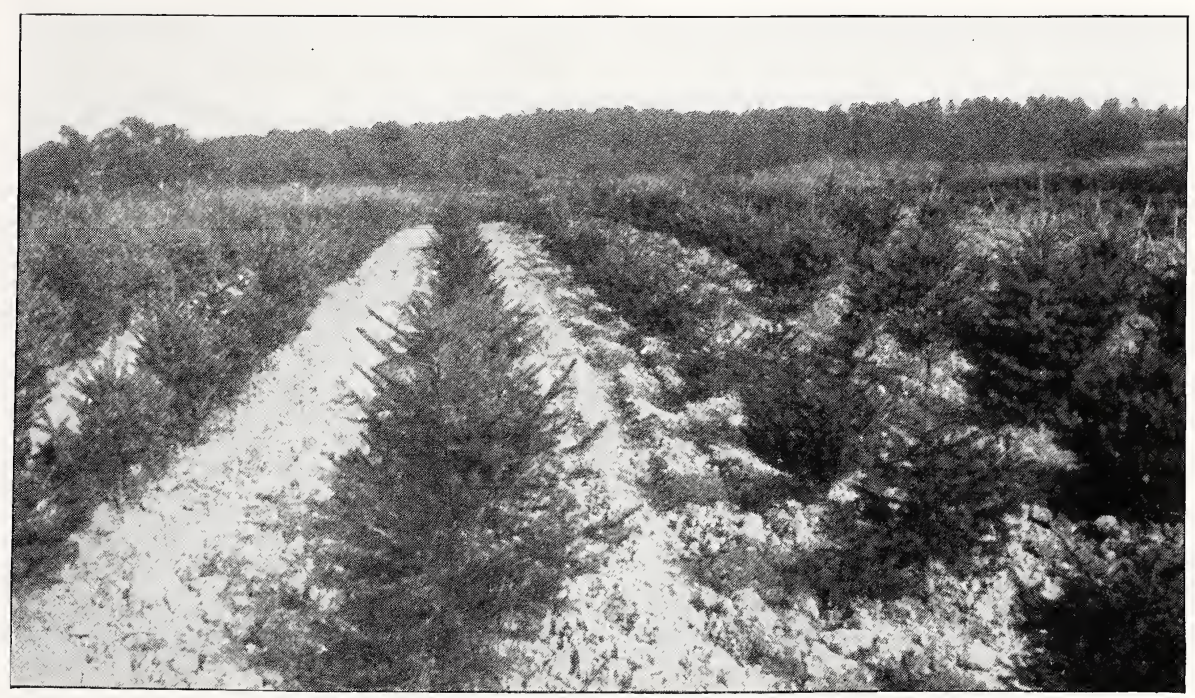

Photo of White Spruce in the Nursery, taken August 1, 1925

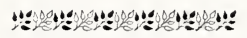

\section{EVERGREENS}

AMERICAN WHITE SPRUCE (Picea alba).

A native evergreen attaining heights from 25 to 50 feet. Very hardy and free grower, silver green in color.

NORWAY SPRUCE (Picea excelsa).

Tall, picturesque and hardy, deep green, with spreading and drooping branches.

RETINOSPORA, PLUMOSA and PLUMOSA AUREA

The above are of the Cypress family, having plume-like foliage. The former green and the latter with golden tip to plume.

(We obtain most of our understocks and "Baby" Evergreens from D. Hill, Dundee, Ill., the largest wholesale grower of Evergreens in America, and any full-grown trees in variety we do not have in stock). 


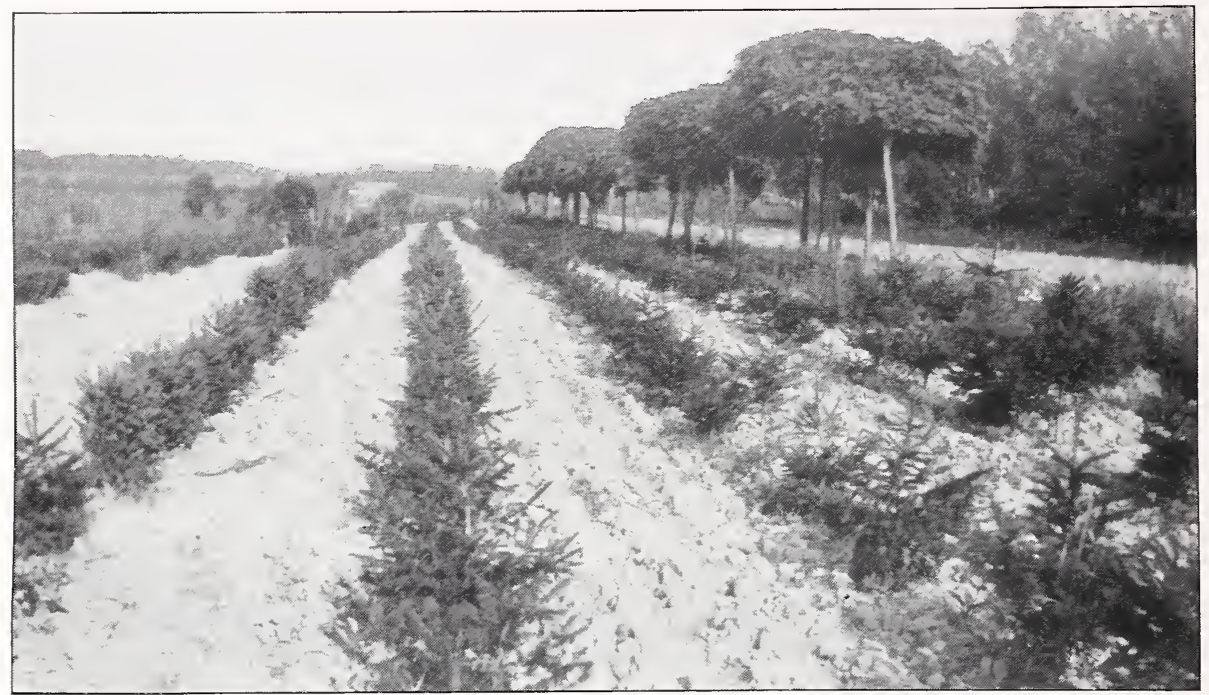

Another View in the Nursery of Norway Spruce and Catalpa Bungeii (or Umbrella Tree)

ABIES BALSAME (Balsam Fir).

Foliage silvery green, rapid grower.

ABIES DOUGLASSI (Douglas Fir).

AMERICAN HEMLOCK (Abies Canadensis).

A very graceful native evergreen.

BIOTA ORIENTALIS (Chinese Arborvitae).

CUPRESSUS SEMPERVIREAS FASTIGIATA (Italian Cypress).

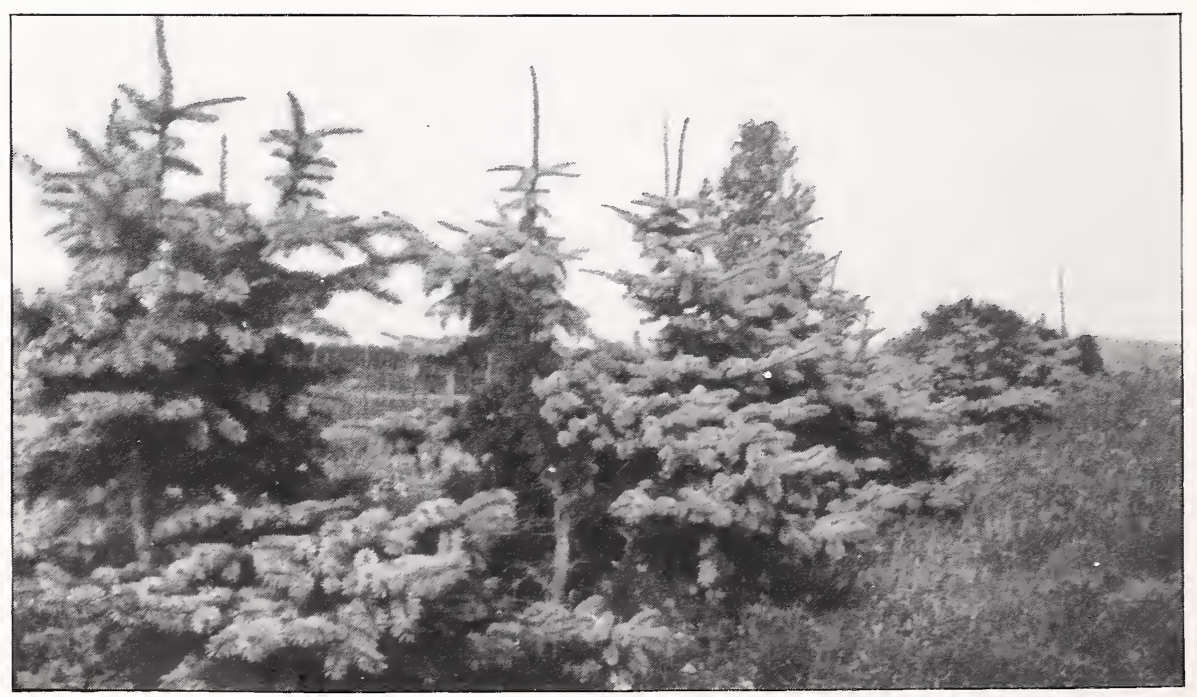

Photo of Koster's Blue Spruce in the Nursery 


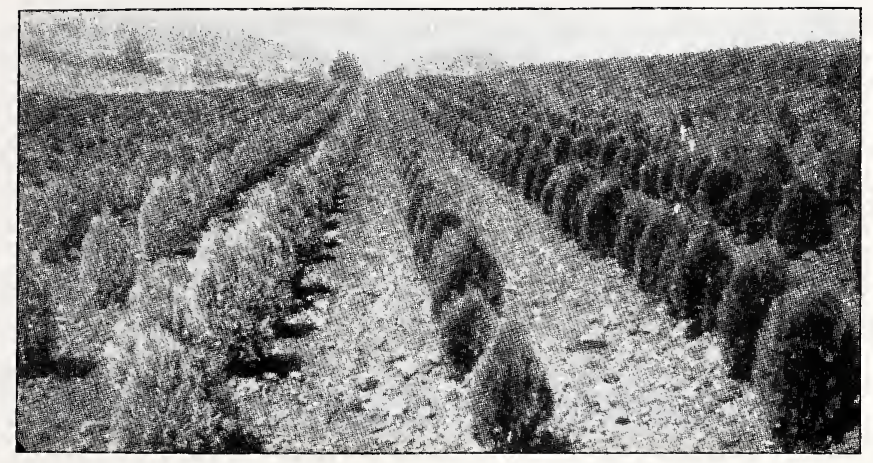

Photo of Berkman's Golden Arborvitae.

The finest of Dwar $f$

Arborvitaes; very compact, with golden tips.

JUNIPERUS CHINENSIS (Chinese Juniper).

Very fine and hardy. Compact, pyramidal in form, bright green, will attain 20 feet.

JUNIPER CHINENSIS PFITZERIANA (Pfitzer's Imniper).

See cut and description below.

JUNIPERUS COMMUNIS HIBERNICA (Irish Juniper).

Very formal in outline, with glaucous green foliage.

JUNIPERUS SABINA (Savin Juniper).

Low spreading, many branched, half erect in habit.

TAXUS CANADENSIS (American Yeze).

Dwarf evergreen growing from two to three feet, dark green.

TAXUS CUSPIDATA (Japanese Yew).

A larger growing tree than the American.

Photo of Pfitzer's

Juniper in center, showing its spreading habits. Fine for ground-cover and at base of group of taller-growing plants.

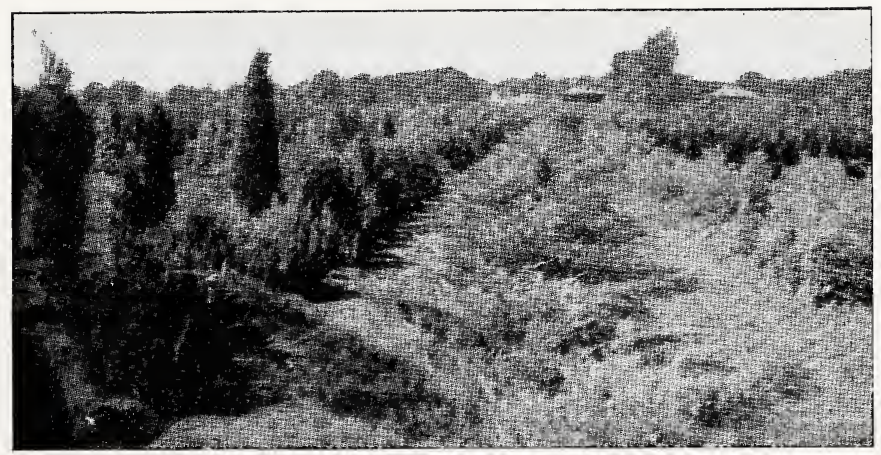




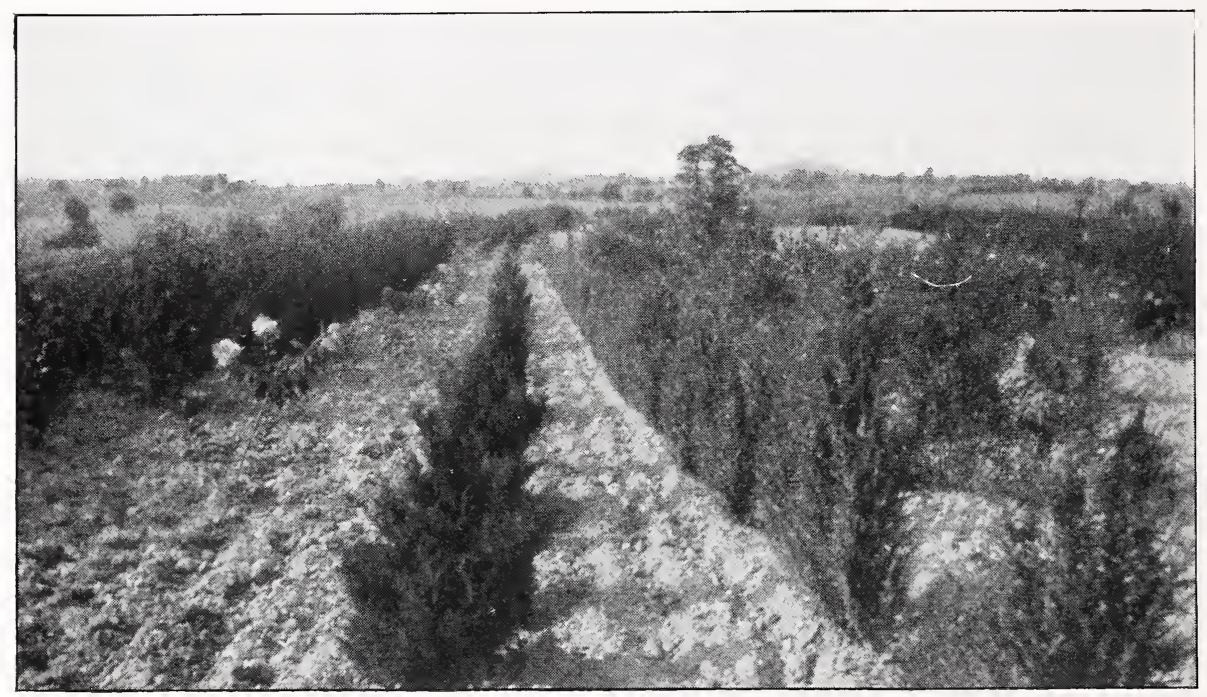

Photo of Evergreens in Nursery, taken August 1, 1925

THUYA OCCIDENTALIS LUTEA (Peabody's Golden Arborvitae).

THUYA OCCIDENTALIS PYRAMIDALIS (Pyramidal Arborvitae). Compact growth, narrow pyramidal form, deep, rich green color, uniform habit and hardy. Full size two feet in diameter and fifteen feet high.

THUYA OCCIDENTALIS SIBERICA (Siberian Arborvitae). Conical in outline, dark green foliage, matures at 6 to 8 feet.

THUYA OCCIDENTALIS WOODWARDI(Woodward's Globe Arborvitae). Maintains globe shape without trimming, reaching three feet in height and diameter.

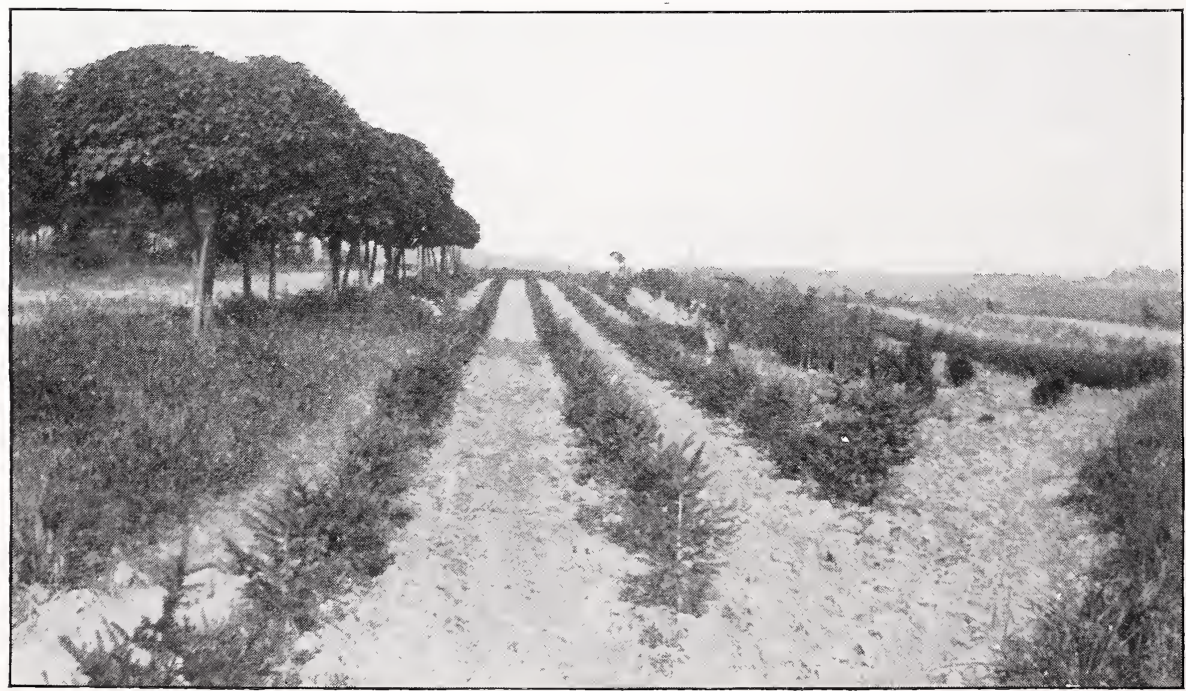

Photo showing more Catalpa Bungeii and Norway Spruce 


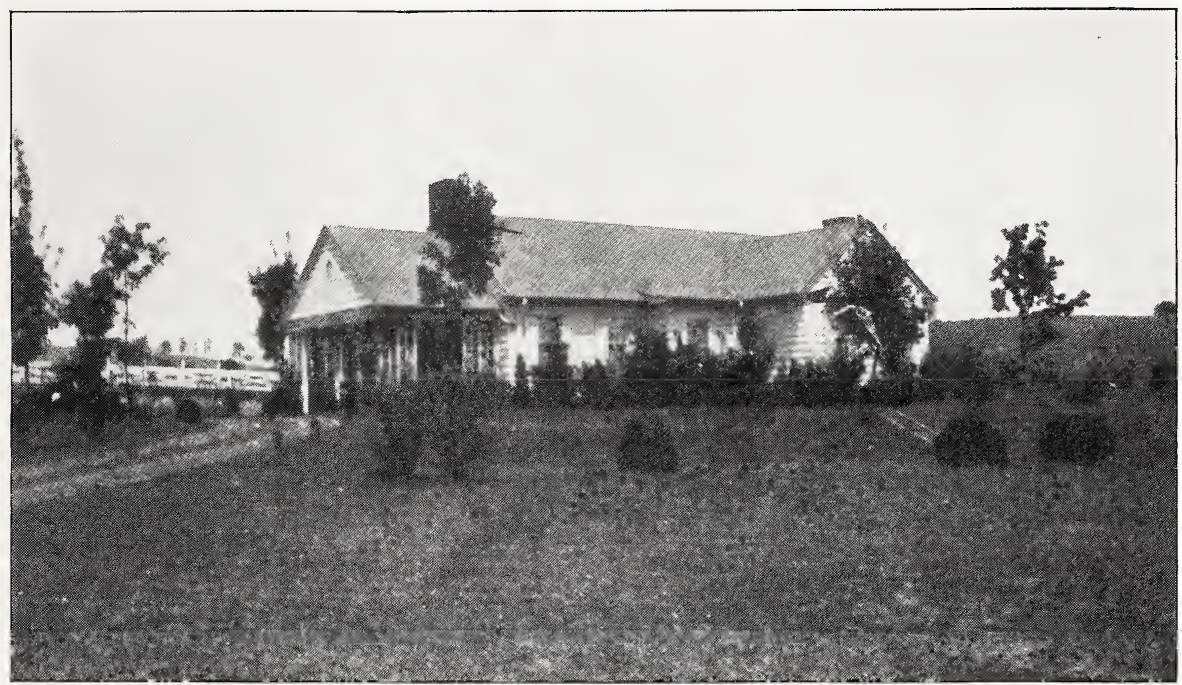

Photo of Mrs. J. C. Gallagher's residence, Fort Defiance, Va., with a planting of evergreens, shrubs and trees from our Nurseries, after being planted two years.

THUYA OCCIDENTALIS aurea nana (Berkman's Arborvitae). Very dwarf, compact, bright golden foliage.

\section{BROAD-LEAVED EVERGREENS}

ABELIA GRANDIFLORA (Bush Arbutus).

A plant blooming all summer, retaining leaves all year.

AZALEA AMOENA.

Fine for grouping.

EUONYMUS JAPONICA.

Large green wax leaf. Dwarf in habit.

EUONYMUS RADICANS.

Yellow flowers all summer.

LIGUSTRUM JAPONICUM (Japanese Privet).

MAGNOLIA GRANDIFLORA.

Very large wax leaf, sweet-scented bloom.

ILEX (American Holly).

CAROLINA CHERRY LAUREL.

FLORIDA CAPE JASMINE. 


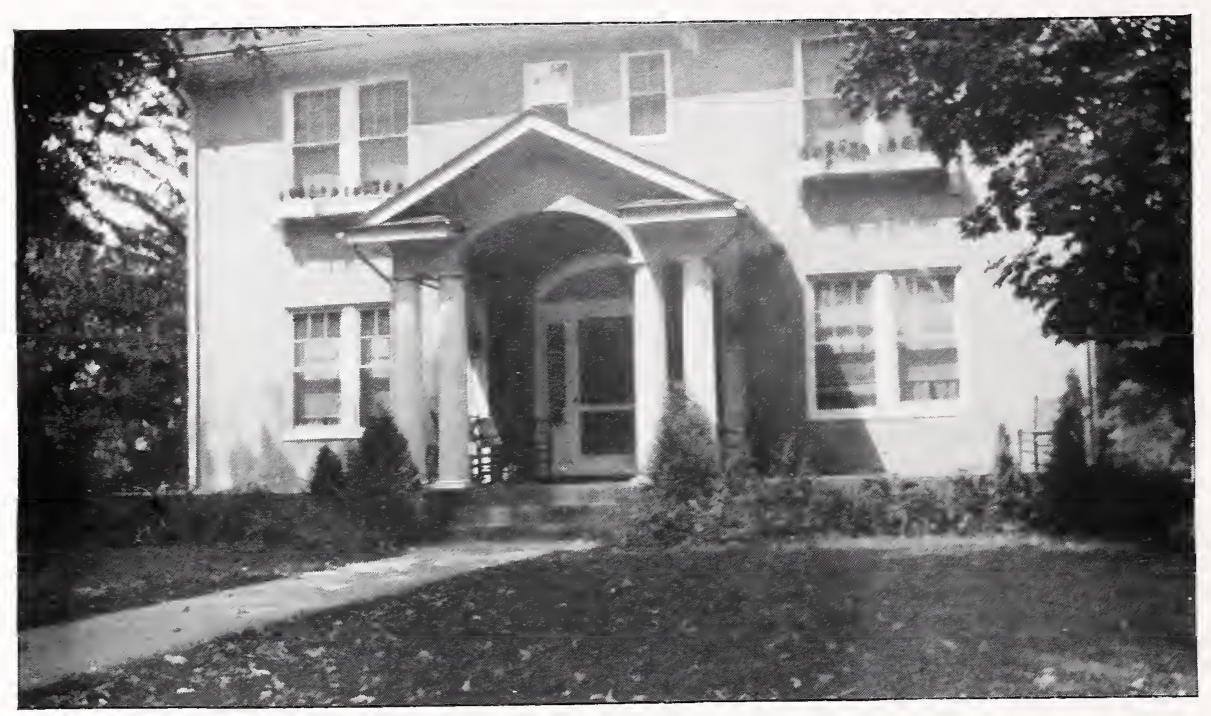

Photo of Mrs. E. B. Crawford's residence. Harrisonburg, Va., one year after planting of evergreens and shrubs. Note the Boxwood in the window-boxes.

BUAUS SEMIPERIIRENS ARBORESCENS (Tree Boxwood).

BLXUS SEMPERIIRENS SLFFRUTICOSA (Dïarf Boxíood).

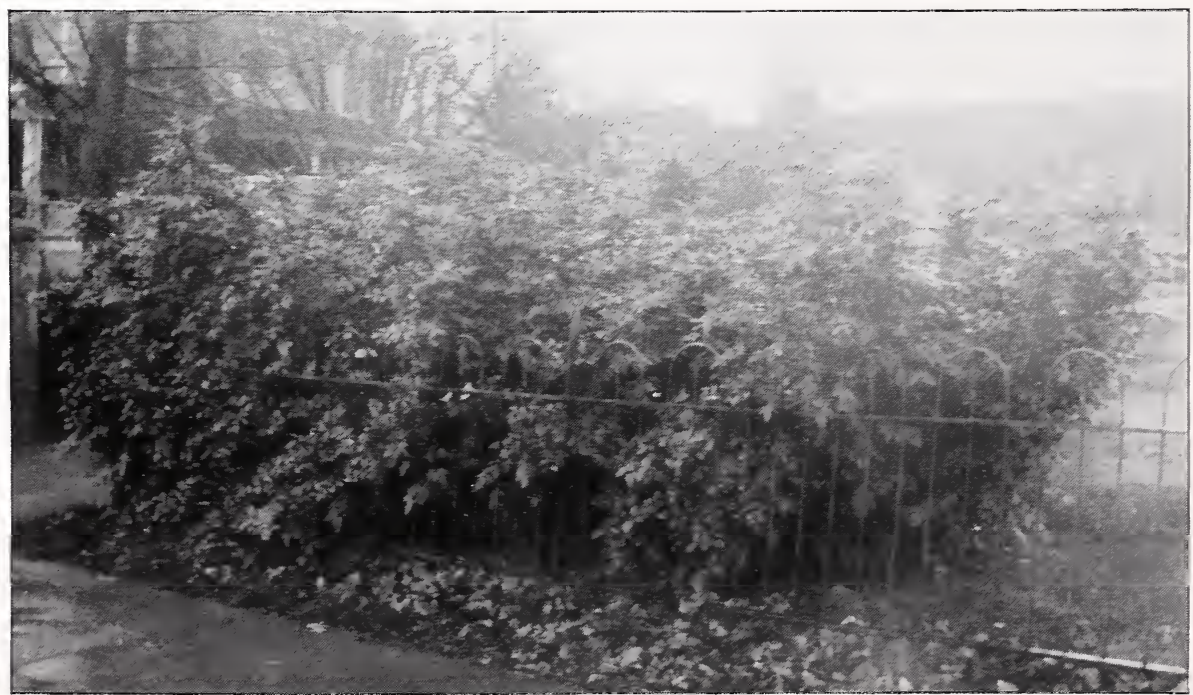

Photo of clump of Mahonia Aquifolium or Oregon Grape. This is a broad leai evergreen, sometimes called Holly-leaved Barberry. Photo taken Dec. 15, 1925. 


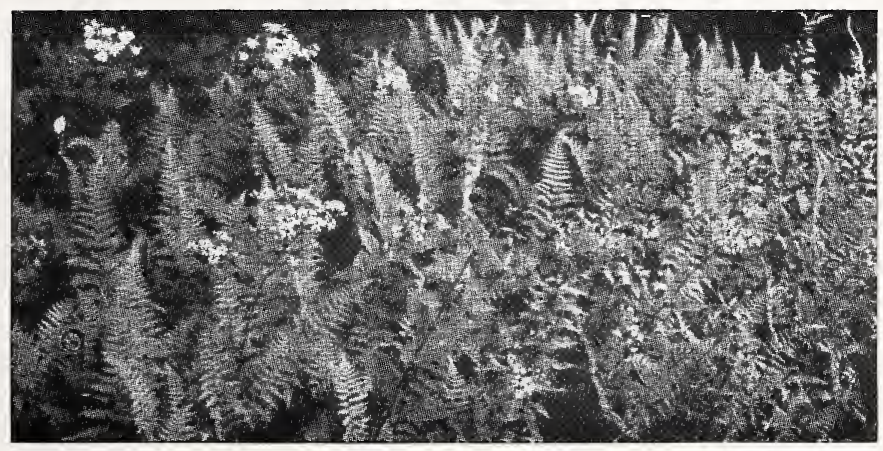

\section{HARDY NATIVE FERNS}

We have both Deciduous and Evergreen Ferns.

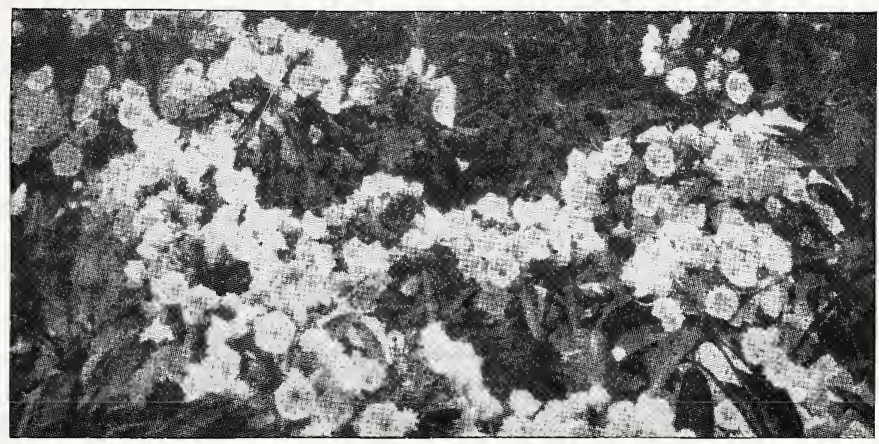

KALMIA LATIFOLIA (Mountain Laurel).

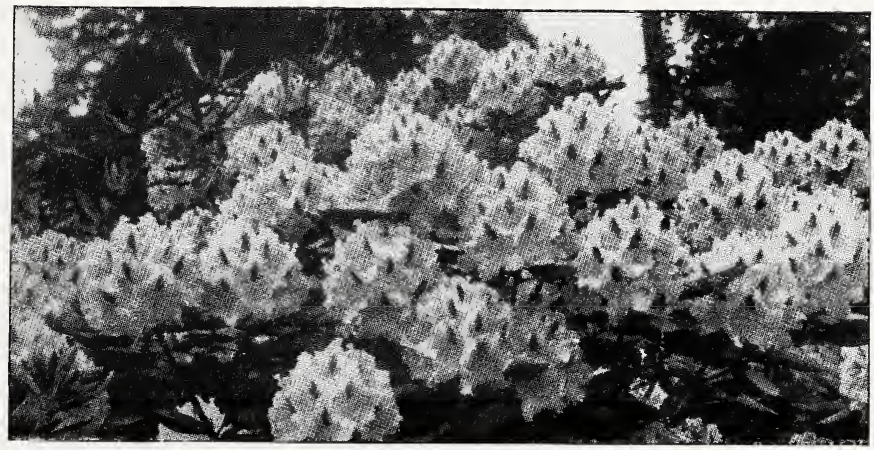

RHODODENDRON (Catawbiense and Carolinianum). 


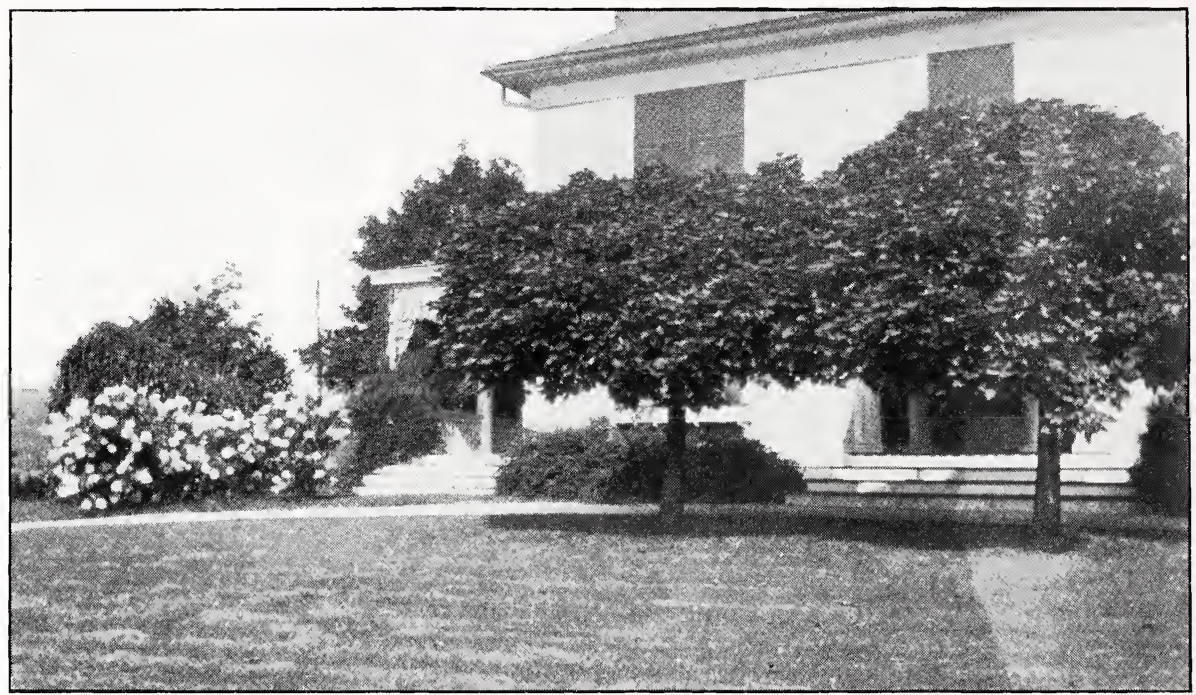

Photo of Col. T. J. Roller's residence, Fort Defiance, Va., showing Catalpa Bungeii, Hydrangea P. G., and Japanese Barberry from our Nurseries.

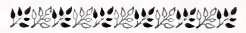

\section{SHADE AND ORNAMENTAL TREES}

NORWAY MAPLE (Acer Platanoides).

The finest of all shade trees, with a round dense head.

SILVER MAPLE (Acer Dasycarpum).

The fastest grower of all the Maple family.

SUGAR MAPLE (Acer Saccharum).

Conical in shape with dense head. Fine.

SCARLET MAPLE (Acer Rubrum).

Best in moist locations; brilliant red autumn coloring.

EUROPEAN WHITE BIRCH (Betula Alba).

Known by its white bark and graceful branches and foliage.

MAIDENHAIR TREE (Biloba Ginkgo).

Covered with white plume-like flowers. Dwarf. 
A UGUSTA NURSERIES

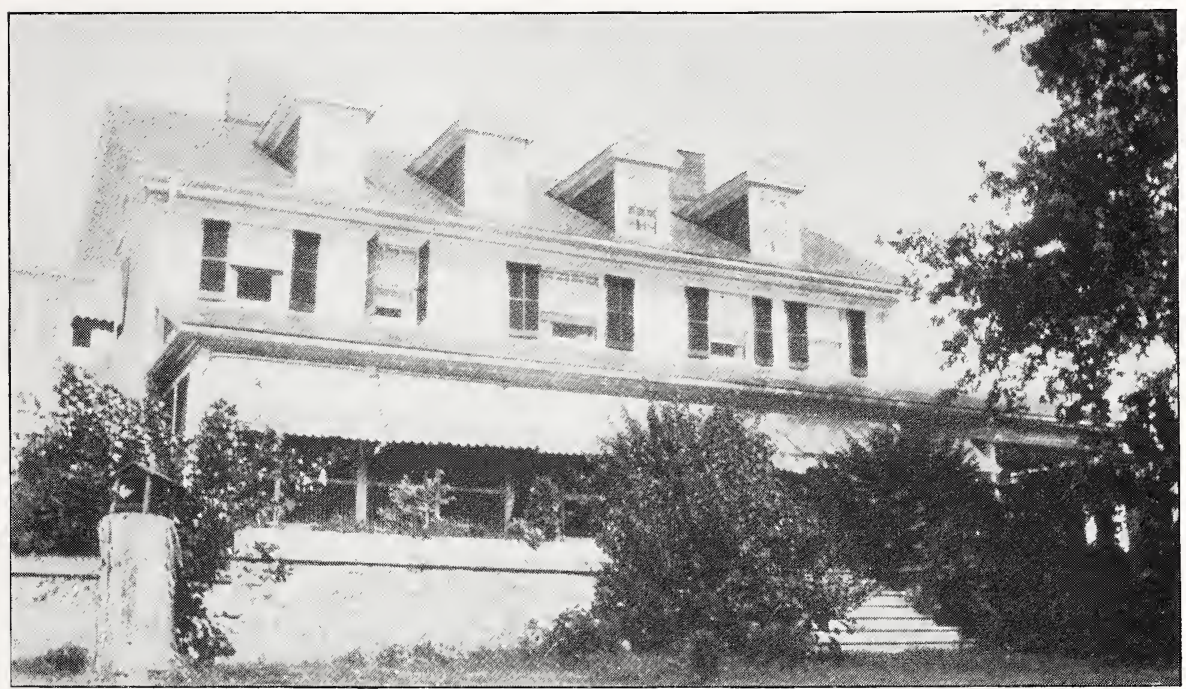

Photo of residence of Major C. S. Roller, Fort Defiance, Va.

SHADES, continued:

CATALPA BUNGEII, or Umbrella Tree.

TEA'S WEEPING MULBERRY .

Shown in cut below.

LOMBARDY POPLAR.

Tall spire-like character, used for screens and background.

PURPLELEAF PLUM (Prunus Pissardi).

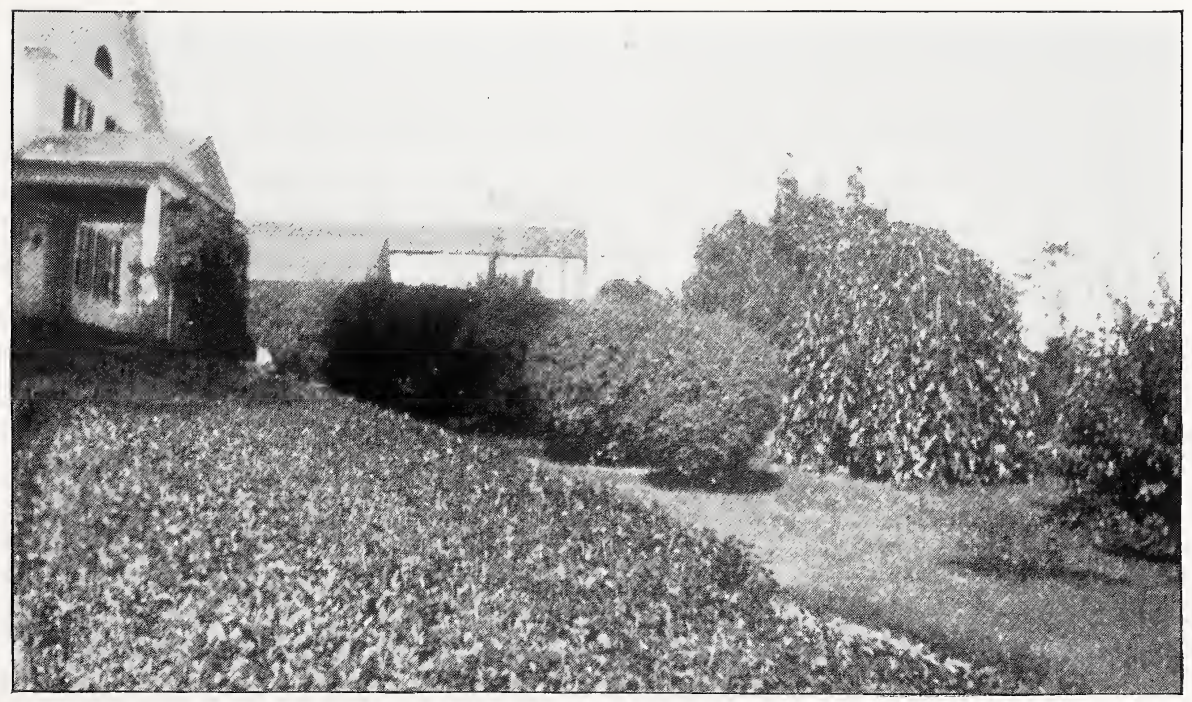




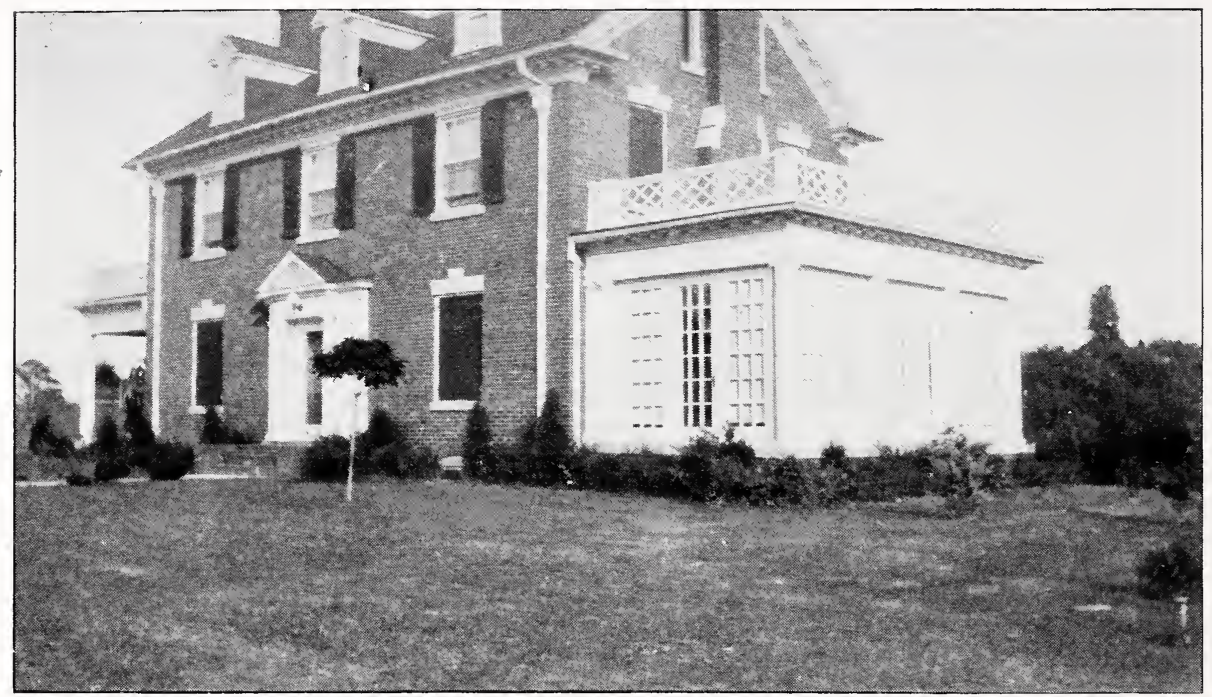

Photo of residence of Mr. William A. Harnesberger, Staunton, Va., taken just after planting.

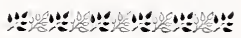

SHADES, continued:

PIN OAK (Quercus Palustris).

RED OAK (Quercus Rubra).

BABYLON WEEPING WILLOW (Salix Babylonica).

AMERICAN LINDEN (Tilia Americana).

AMERICAN ELAI (Ulmus Americana).

Upright growth.

CAMPERDOWN ELM (Ulmus Camperdormi).

Weeping.

MOUNTAIN ASH (Sorbus Aucuparia).

EUROPEAN PLANE TREE (Platanus Oricntalis).

TULIP TREE (Liriodendron Tulipifera). 


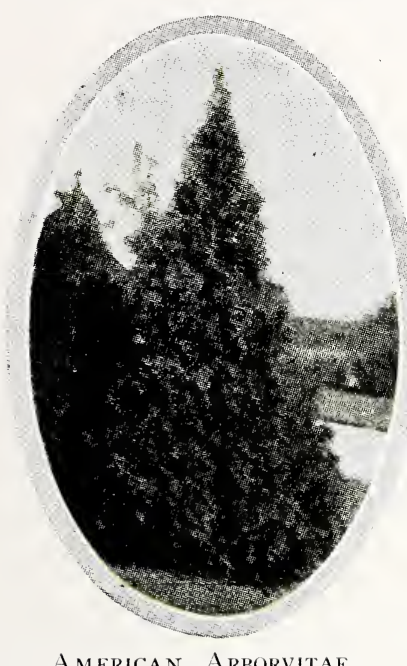

American Arborvitae

\section{EVERGREENS}

\section{Our Evergreens are all Compact, and Niccly} Shaped Spccimens.

Evergreens are valuable trees to plant on your grounds. During summer evergreens are as attractive as other trees, but not until the winter days approach us is the evergreen so much admired. They are never quite so beautiful as when branches are bowed with banks of white snow. A few evergreens planted on your grounds will also create warmth and save fuel.

\section{IRISH JUNIPER}

The trees form low, dense cones of silvery green. No lawn is complete without at least one of these trees.

\section{JUNIPER PFITZERIANA}

Its sweeping, gray-green branchlets give this broad, bushy type value for mixed planting.

JUNIPER ROSEDALE (Hybrid)

A tall conical grower, very compact, foliage light green with a fir-like appearance.

PYRAMIDAL

AMERICAN

ARBORVITAE

Its tall, slender habit makes it splendid for formal use; a dense dark green columnar form.

\section{CHINESE ARBOR-} VITAE

Tall and slender; rich dark green. For formal work.

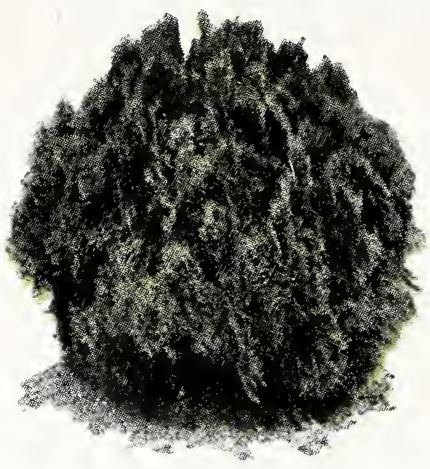

Globosa Arborvital

JUNIPER HORIZONTALIS

(Creeping Juniper). Very low and compact, making a dense mat. Soft blue color in spring and summer, changing to rich purple color in late fall. Grows close to the ground, about 6 to 12 inches in height, but spreads out several feet, depending upon soil and planting conditions.

\section{AMERICAN ARBORVITAE}

Rather dwarf habit of growing. Its foliage or leaves are flat instead of needle-like, and set on edge, color bright green. One of the most extensively planted of all evergreens. Used as specimens for the lawn, and in tubs for porches, also extensively planted for hedges and screens, to break the force of winter winds. Fast grower for first 4 years, after this dwarf habit of growing.

\section{GLOBOSA ARBORVITAE}

A new variety that is very handsome. In shape it is absolutely round or globular. Very dense in growth, and does not require shearing. It does not grow over 4 or 5 feet tall; foliage is dark green, its little branches being of unusual delicacy.

\section{GOLDEN ARBORVITAE}

(Biota aurea nana). Conical form, very dense and compact. l)uring spring and summer it presents the most cheerful brightyellow-green imaginable, changing to old gold in autumn.
TOM THUMB ARBOR VITAE

This is one of the most beautiful of the dwarf evergreens. Its foliage resembles both the American Arborvitae and the ked Cedar. The tree grows low and dense, never higher than 3 or 4 feet.

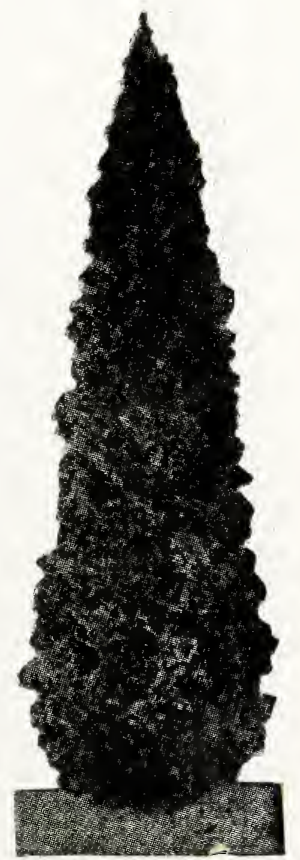

Pyramidal Arborvitae 


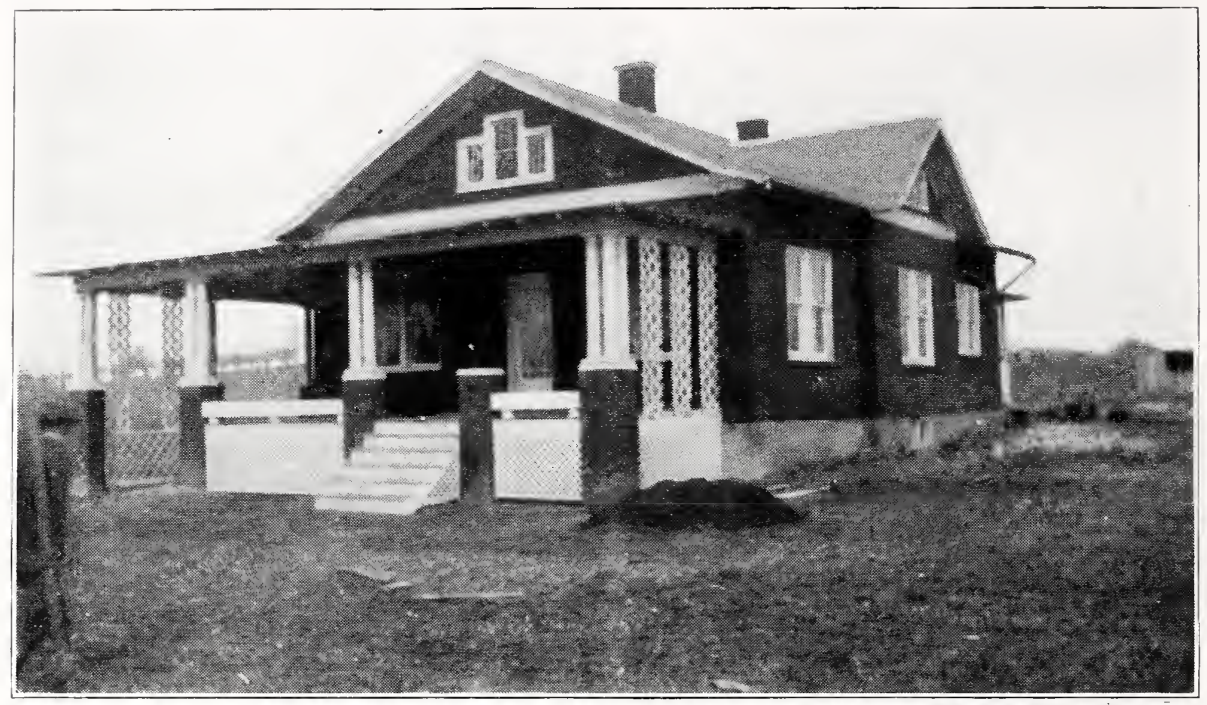

Photo of residence of Mr. John H. Tutwiler, at Weyers Cave, Va.

Above, before planting-below, after planting.

\section{$\because \because \because \because \because \because \because$}

The grouping below is made up of dwarf-growing evergreens and shrubbery.

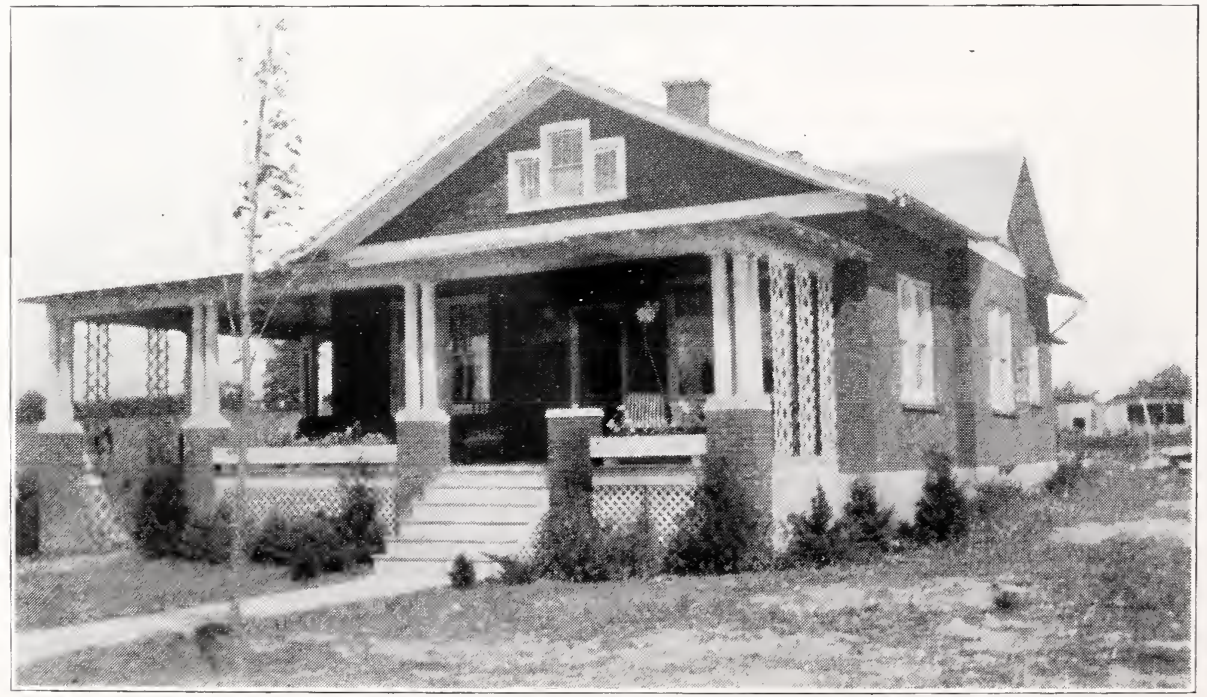

Photo taken just after planting. 


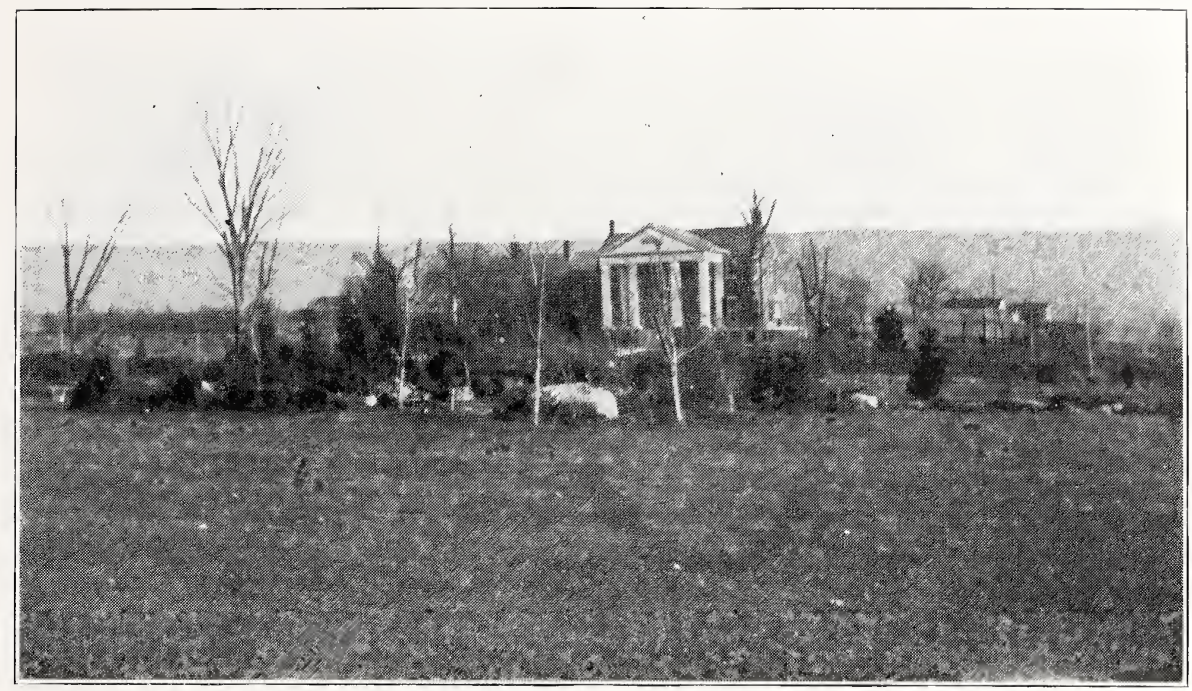

Above is another photo of the present residence of Mr. W. Starke Kilmer, Court Manor, New Market, Va.

He now has under construction a $\$ 100,000$ club-house on this farm, which, when completed, will be unequalled in the Valley by any private owner.

After this structure is finished, these grounds and the race-horse breeding farm will be one of the most interesting show-places of the Shenandoah Valley, over $\$ 50,000$ will have been expended in landscaping and shrubbery alone.

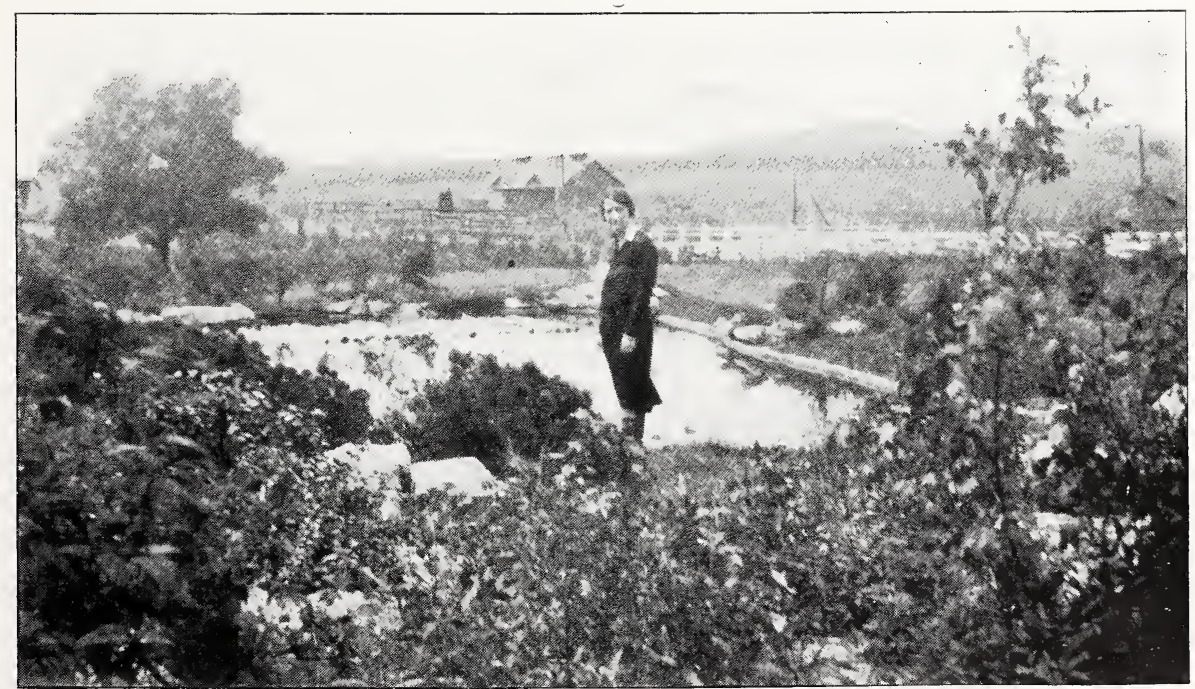

Photograph of Trout Pool in the Beautiful Lawn of Court Manor. 


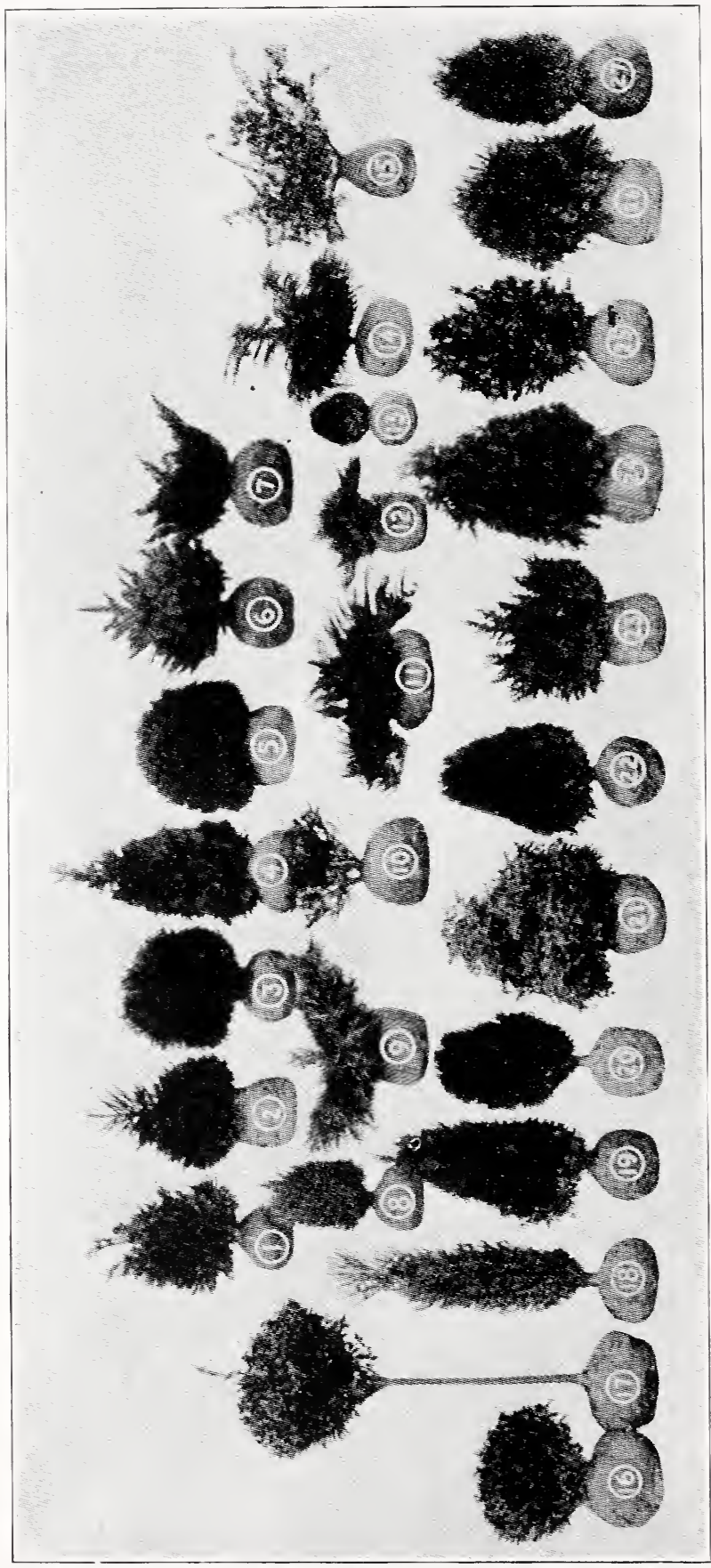

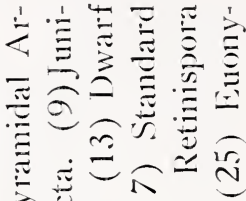

$\sum$.

于

-

记主导心总

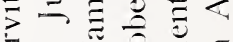

Ðே心

य.

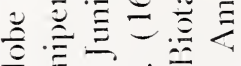

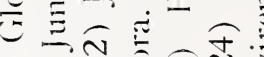

$\widetilde{\sim} \equiv \cong \cong \widehat{\equiv} \mathbb{N}$

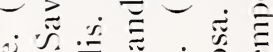

次焉芯芯

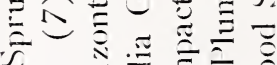

$\rightarrow$ ن

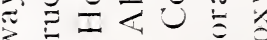

宊

乙。引 $\cong$

กิ记式

그를

을 $\frac{\bar{\sigma}}{\mathrm{N}}$

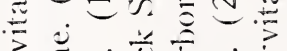

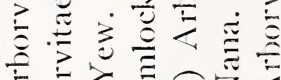

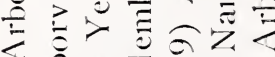

$\checkmark \cong$

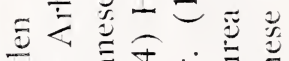

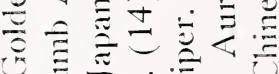

$\because \equiv-\dot{\Xi} \Xi$

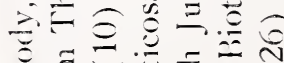

$\Xi \Xi \Xi \frac{\mathrm{N}}{\Xi}$

$\approx=$

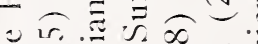

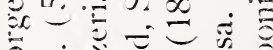

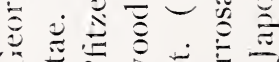

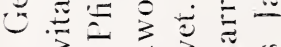

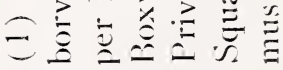

This photograph has been specially prepared by us for the convenience of our customers in selecting their Evergreens. The caption on the right is a key to each variety as per number listed on ball and burlap of each tree. 
A U GUSTA NURSERIES

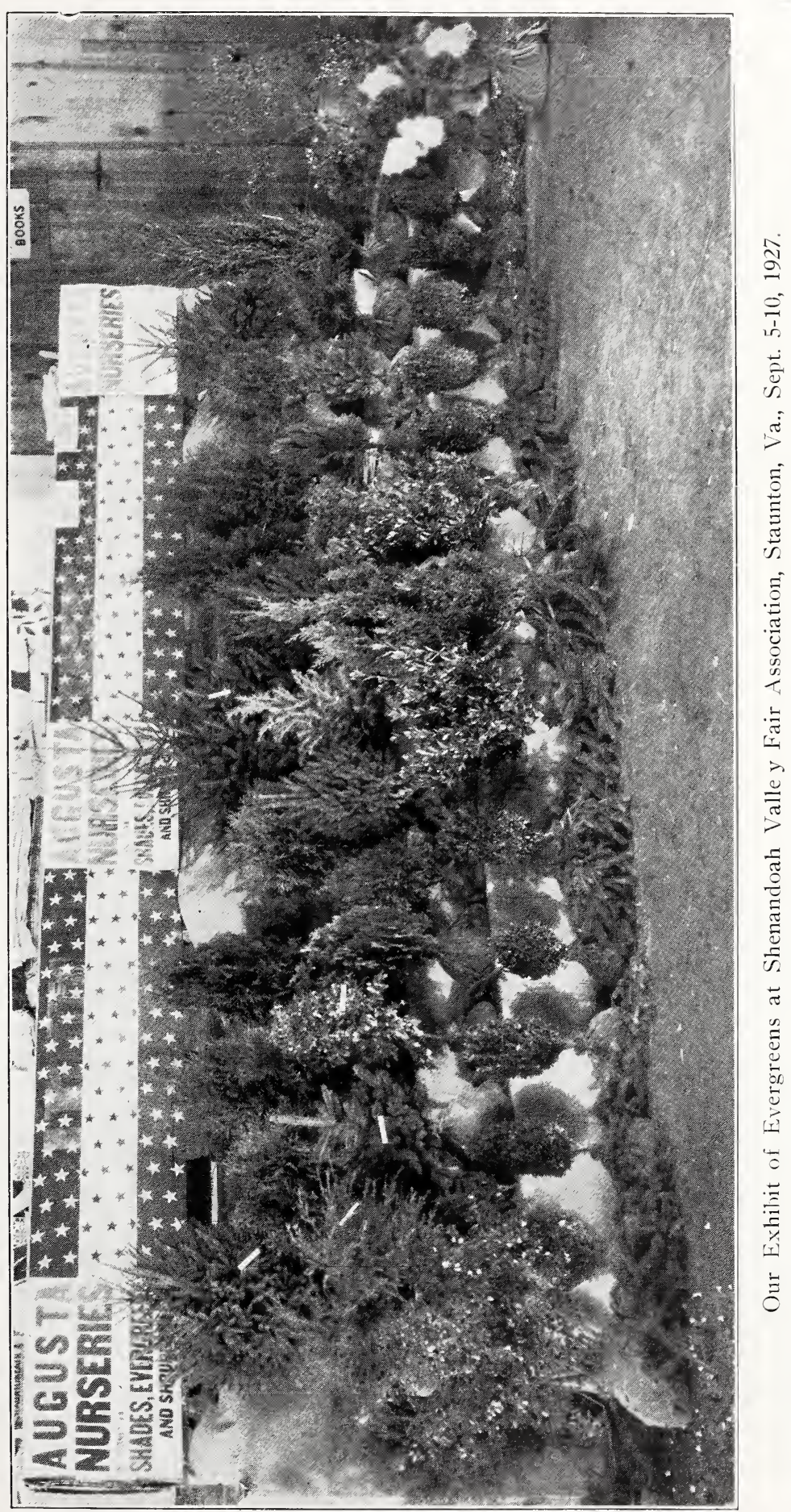




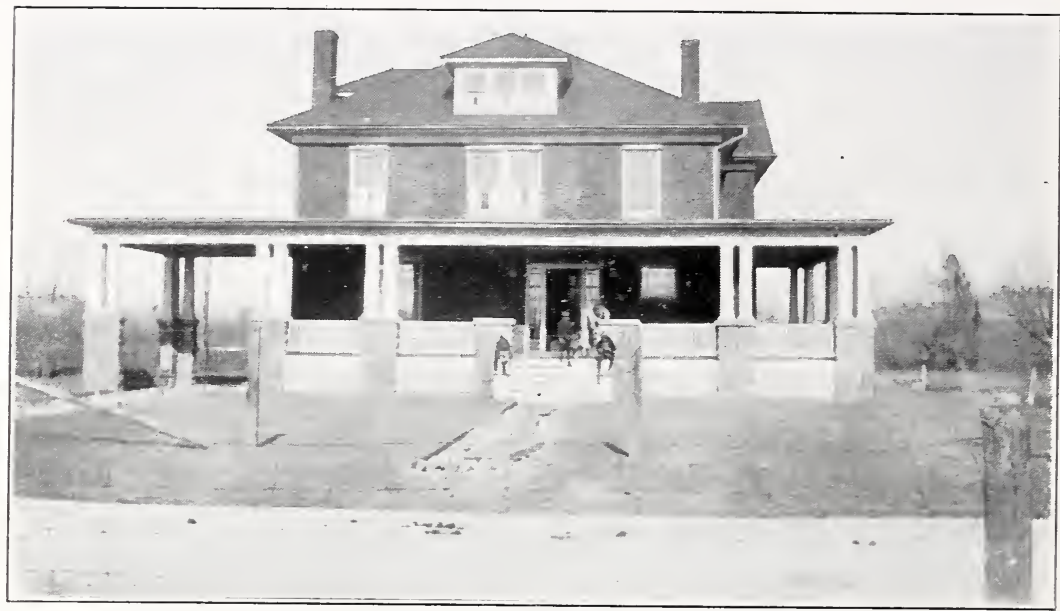

Photo of residence of Mr. L. E. Long, at Rockland Mills near Weyers Cave, Va.

$$
\because \because \because \because \because \because
$$

Above, before planting. Below, after planting.

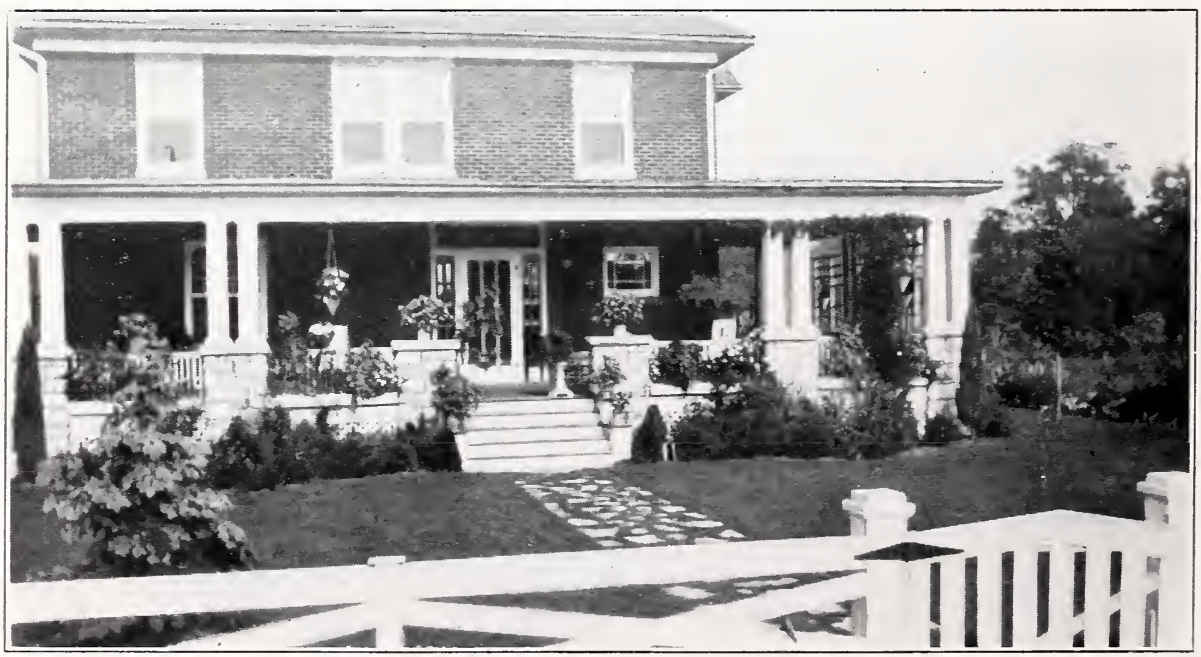

We are planting an extensive evergreen and shrubbery garden to the right of this photo. 


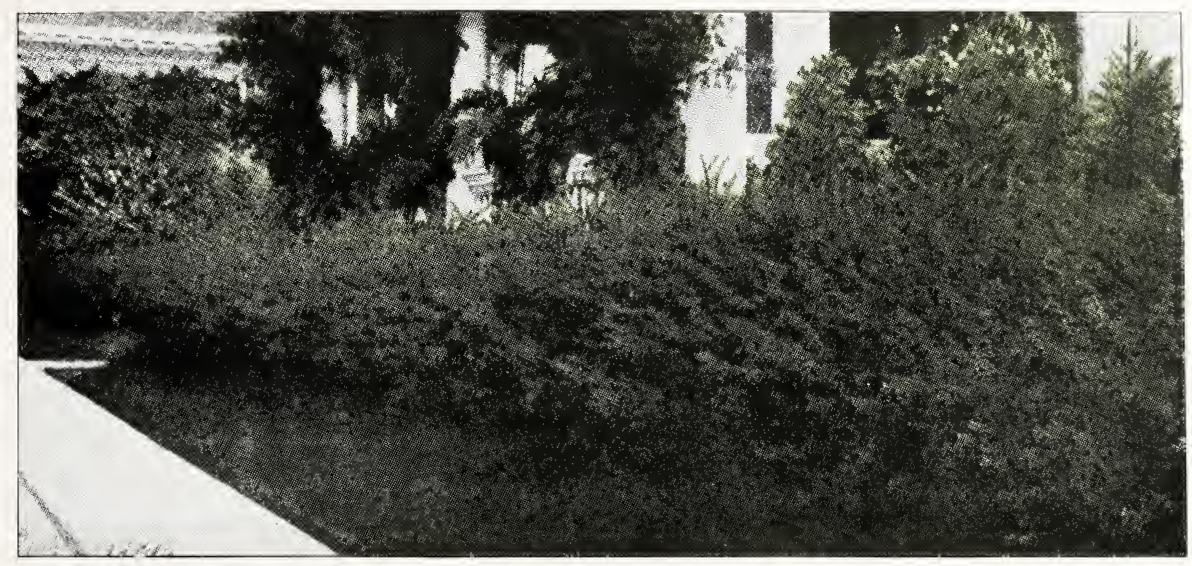

The above is a Japanese Barberry hedge.

The Japanese Barberry is one of the best of plants for hedging, mixed in groups and for protection to other plants. Very hardy and easily grown. Green all Summer, turning scarlet in Fall and carrying red berries thru Winter, giving color all year.

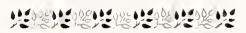

Below is a California Privet hedge with a background of Howering shrubs. This is a very popular hedge plant and very easily grown. It can be pruned to any shape or can be let grow to a considerable height.

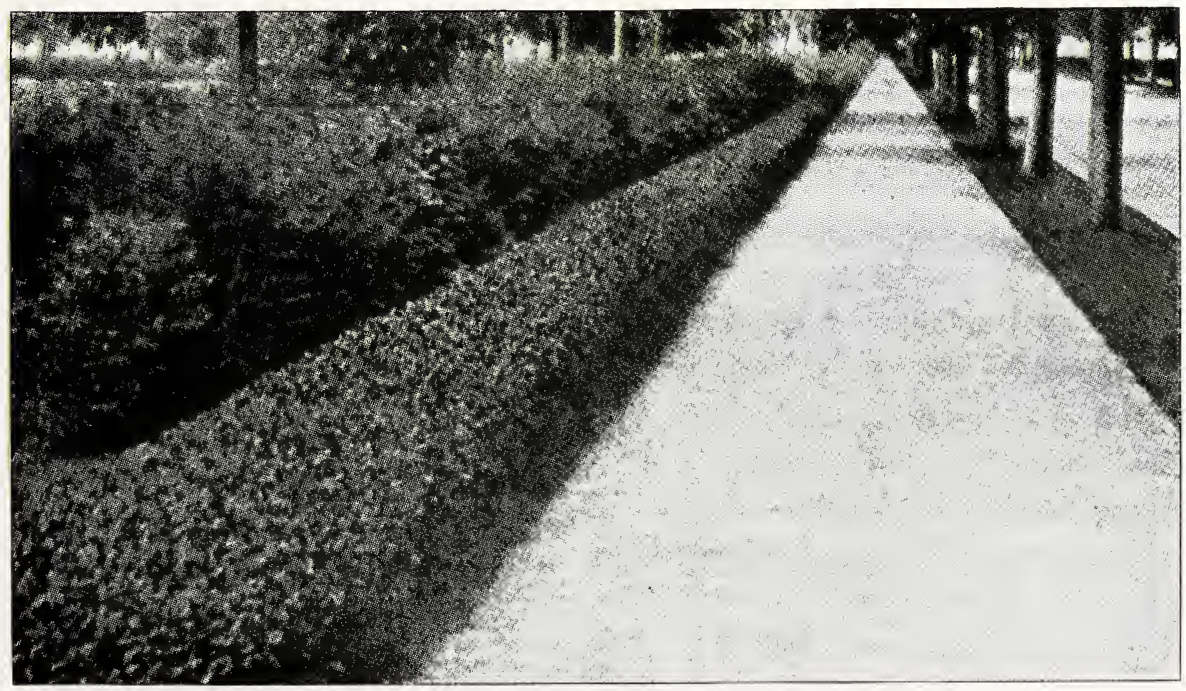




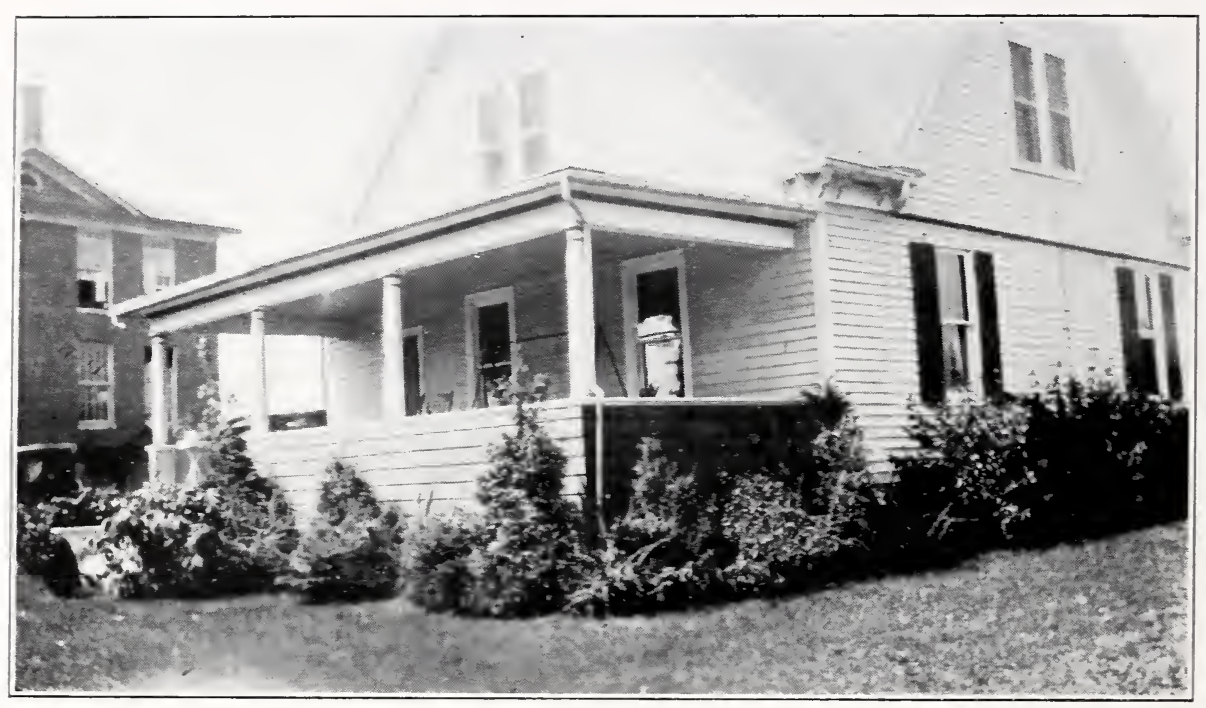

Photo of residence of Mr. M. C. Leonard, at IVeyers Cave. Ta.

In this grouping evergreens predominate, giving a bright. warm appearance in Vinter. To the right is an evergreen and shrubbery garden which does not appear in this photo.

\section{$\because \because \because \because \because$}

Below is a Norway Maple with a bachground of a miniature spruce forest. Hundreds of song birds nest therein.

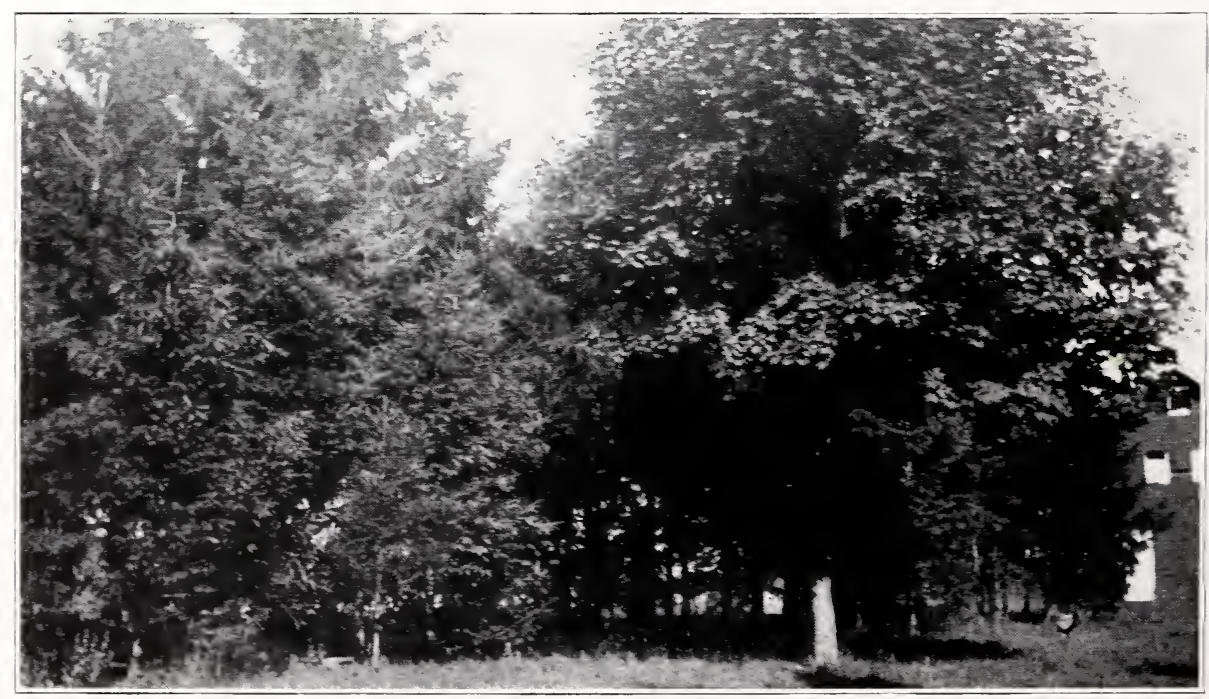




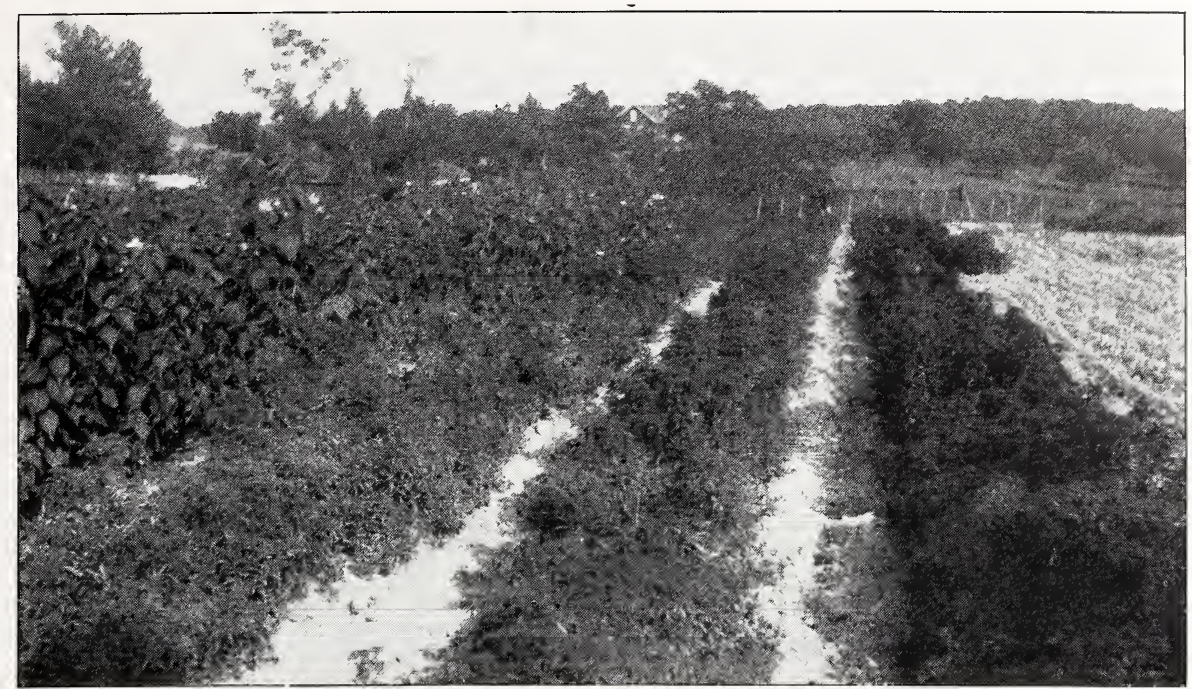

Photo in Nursery Showing Spirea Anthony Waterer and Marvel Mallows

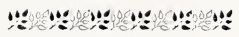

\section{DECIDUOUS SHRUBS}

Prices on Shrubs depending on size and age of clumps, varying from 50 cents to $\$ 1.00$ per clump or plant.

A plant two to four years old will bloom and be effective first year after planting. This age and size, $\$ 1.00$ each.

\section{ALTHEA (Rose of Sharon).}

Double pink, red, and white. Continuous bloomer.

BUDDLEIA MAGNIFICA (Butterfly Bush).

Profuse bearer of sweet-scented lilac bloom. Very fast grower. Will bloom first year. (Should be cut back each year in early Spring).

CERCIS CANADENSIS (Red Bud).

Rosy-pink, very effective with Dogwood. 


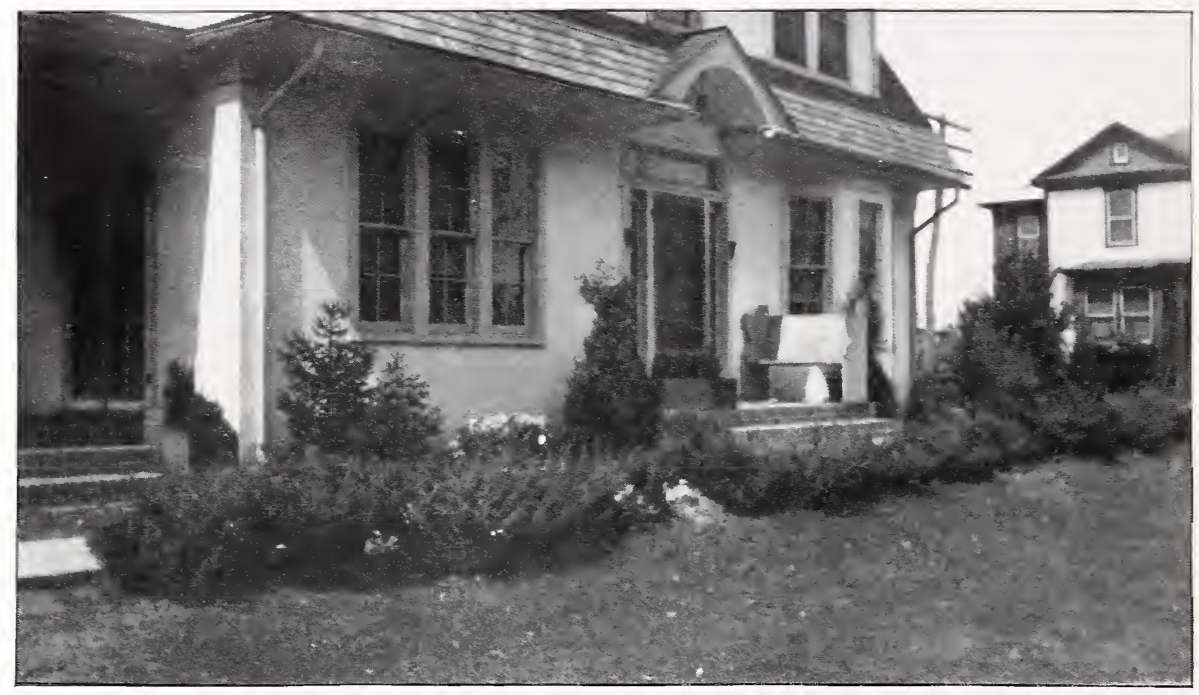

Photo of Mrs. P. H. Hardy's residence, Harrisonburg, Va., showing Juniperus, Communus and Sabina.

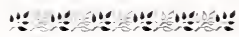

\section{SHRUBS, continued:}

CORNUS, Florida (White Flowering Dogwood).

Flowering very profusely. Large white.

CORNUS, Stolonifera (Red-Osier Dogwood).

Spreading habit, dark red bark, white truit.

CORNLS. Lutea (Golden Bark Dogwood).

Has distinct yellow bark, fine for winter effects.

CORNUS, Rubra (Red Flowering Dogwood).

The most beautiful and rarest of its family.

CIDONIA, Japonica (Japanese Flowering Quince).

Scarlet flowers in April, May:

SAMIBUCUS, Aurea (Golden Elder). 


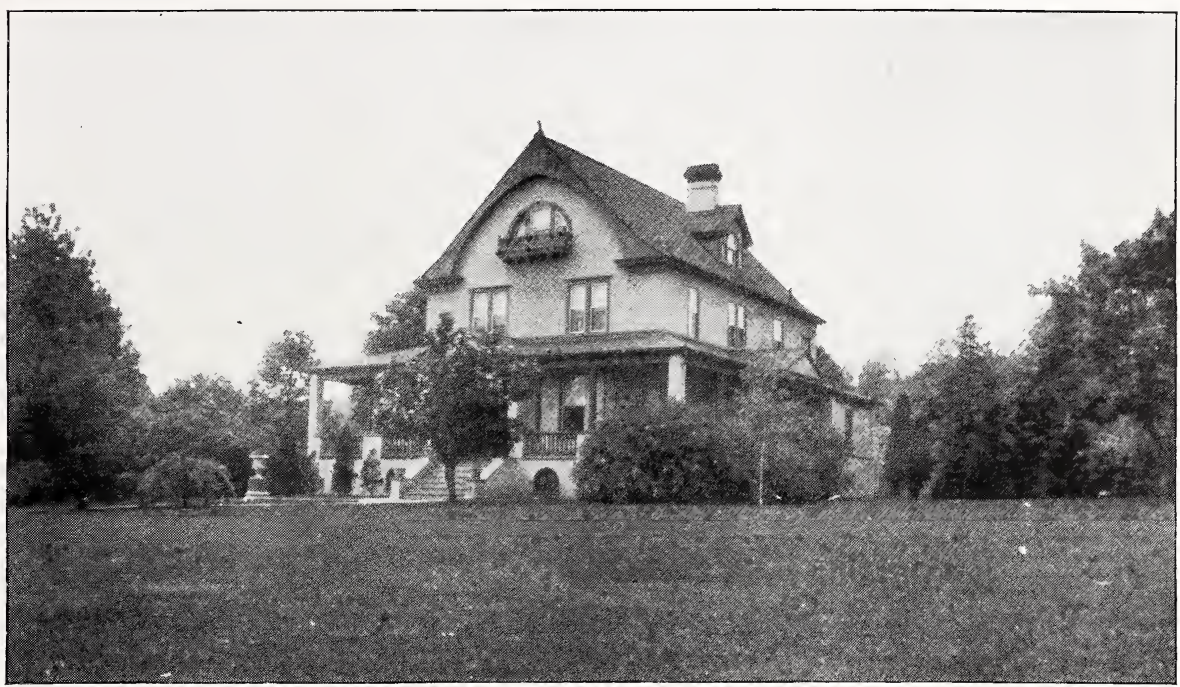

Photo of residence of Mr. H. L. Lang, Staunton, Va. Large clump of Spirea Vanhouttei at side of porch. This is one of the most beautiful lawns in Staunton and we furnished most of the plants shown.

\section{DECIDUOUS SHRUBS, continued:}

DEUTZIA, Crenata (Double Pink Deutzia).

Pink, slightly fragrant, June.

DEUTZIA, Gracilis (Slender Deutzia).

Profuse bloomer, pure white, May.

DEUTZIA, Pride of Rochester (Large Flowering Deutzia).

Vigorous, large flower, June.

FORSYTHIA, Suspensa (Weeping Golden Bell).

Graceful drooping habit; excellent for massing or banking.

FORSYTHIA, Viridissima (Green Stem Forsythia).

Very vigorous, green bark, dark green leaves. 


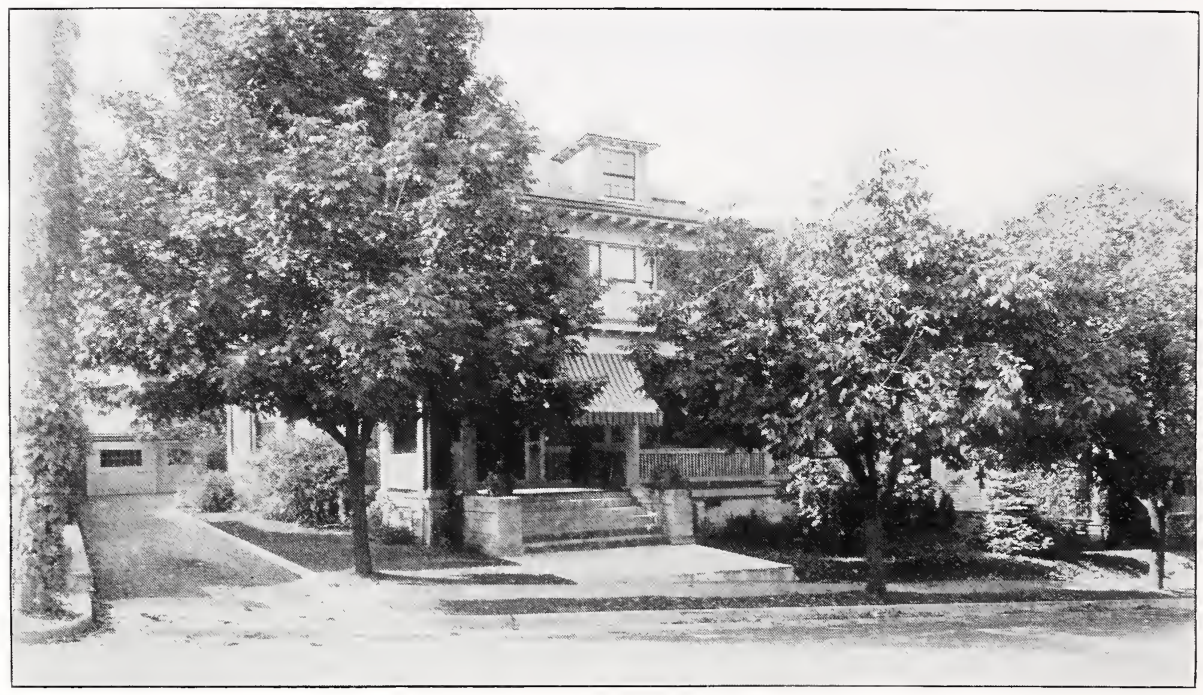

Photo of residence of Mrs. William Dean, Harrisonburg, Va., showing Norway Naples and other shrubbery.

\section{SHRUBS, continued:}

HAMAMELIS, Virginiana (Witch-Hazel). Yellow ribbon-like flowers, bushy habit. October, November.

HYDRANGEA Paniculata Grandiflora (P. G.) Bears long, loose panicles of white flowers, turning pink in fall.

HYDRANGEA P. G. Standard (Tree Hydrangea). Just like the P. G. bush form, except tree form.

HYDRANGEA Aborescens Grandiflora (A. G.) (Hills of Snow). Large double white panicles, very showy.

HYDRANGEA Quercifolia (Oak Leaf Hỵdrangea). Large oak-shaped leaf, splendid autumn coloring.

LONICERA, Morrowi (Morrow Honeysuckle). Spreading habit, white, red fruit, good foliage.

LONICERA, Tatarica. Pink, Red and White. Flowers and fruit freely produced. 
A U GUSTA NURSERIES

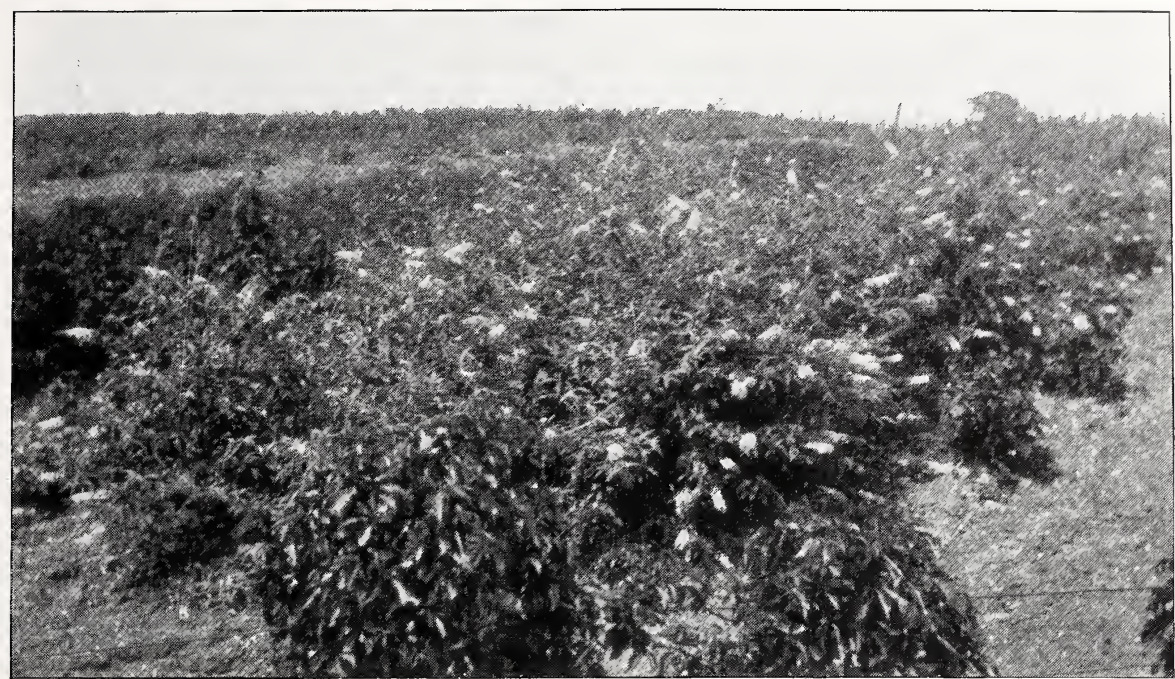

Photo in Nursery of Butterfly Bush (Budlea Magnifica)

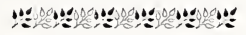

\section{SHRUBS, continued:}

SYRINGA, Persica (Persian Purple Lilac).

Deep purple lilac flowers, profuse bloomer.

SYRINGA, Persica Alba (White Persian Lilac).

SYRINGA, Vulgaris (Common Purple Lilac).

SYRINGA, Vulgaris Alba (Common White Lilac). Also have some French varieties of Lilacs.

MARVEL MALLOWS in red, pink and white.

PHILADELPHUS, Coronarius (Sweet Mock Orange). Profuse white fragrant flowers in May, June.

PHILADELPHUS, Grandiflora (Large Flowering Mock Orange). Large flowers. No fragrance.

PHILADELPHUS, Lemoinei (Lemoine Mock Orange). Good compact habit. Flowers sweetly scented. 


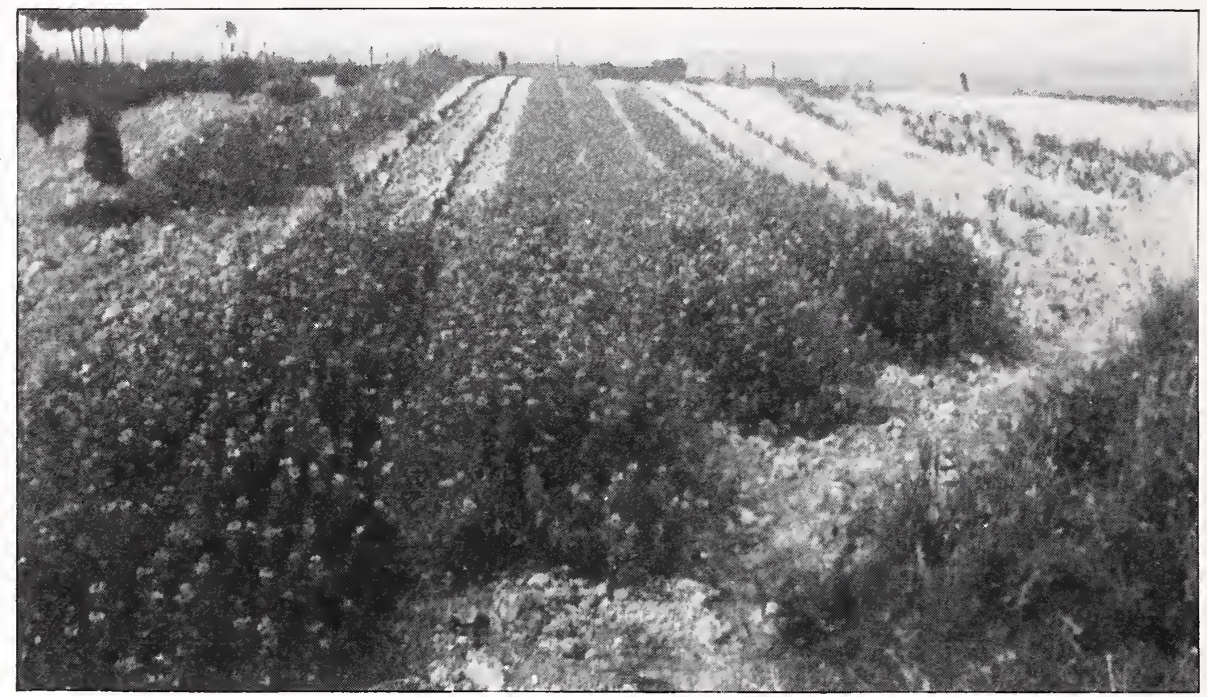

Photo in Nursery of Blue Spirea (Masticanthus Caryopteris). This plant carries a mass of indigo-blue flowers continuously until frost.

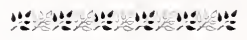

\section{SHRUBS, continued:}

PHILADELPHUS, Virginalis (Virginal Mock Orange).

An everblooming Mock Orange. Have had fine bouquets of this shrul in October. Large, snow-white, crested and semi-double bloom. Very sweetly orangescented. Fine for flowering hedge or as individual plant.

PRUNUS, Pissardi (Purpleleaf Plum).

JASMINUM, Nudiflorum (Winter Jasmine).

Yellow. April-May. One of first to bloom in Spring.

SYMPHORICARPOS, Racemosus (White Snowberry).

Gray-green foliage, holding white berries in winter.

SYMPHORICARPOS, Vulgaris (Red Snowberry or Coralberry). 


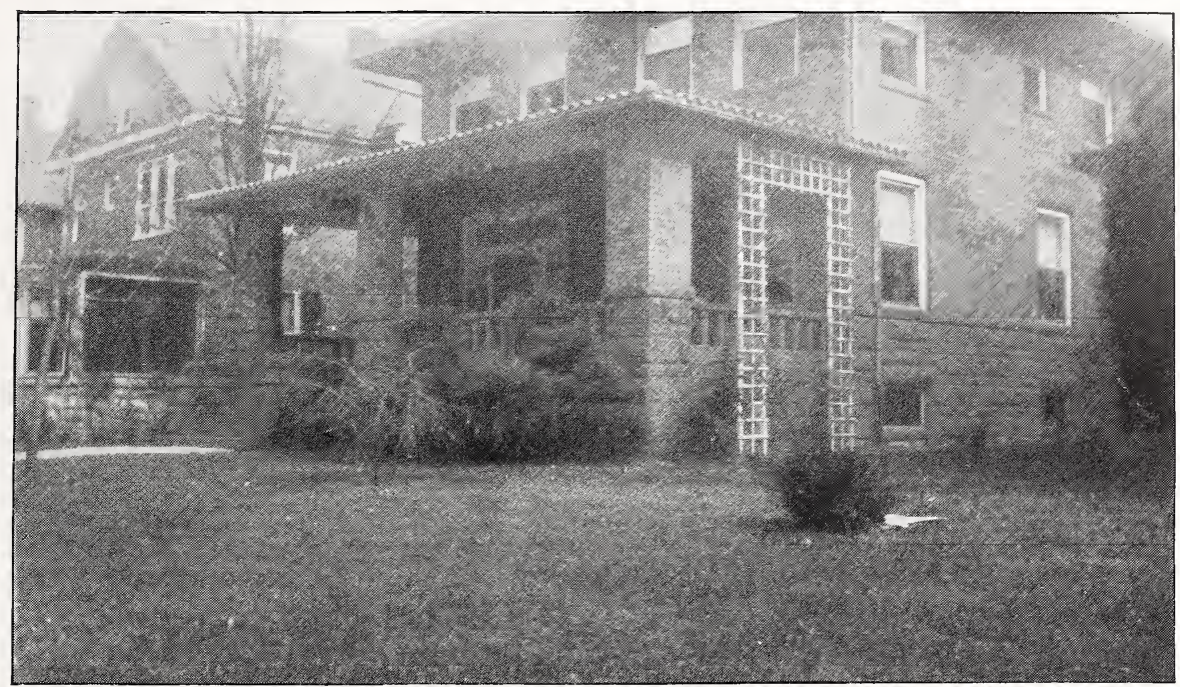

Photo of residence of Mrs. Dr. C. E. Conrad, Harrisonburg, Va.

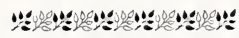

\section{SHRUBS, continued:}

SPIREA, Vanhouttei (Bridal Wreath).

A very profuse white bloomer; best of all Spireas. We have extra large clumps of this variety.

SPIREA, Anthony Waterer. (Pink Spirea).

A dwarf variety. A very profuse bloom of pink fleece-like bloom, lasting some months.

SPIREA, Aurea (Goldenleaf Ninebark).

A bright golden foliage, with white bloom.

SPIREA, Japonica (Japanese' Spirea).

White, June-July. Purplish-green foliage.

SPIREA, Blue (Caryopteris Masticanthus).

A very desirable plant, bearing a mass of indigo-blue flowers continuously until frost. 


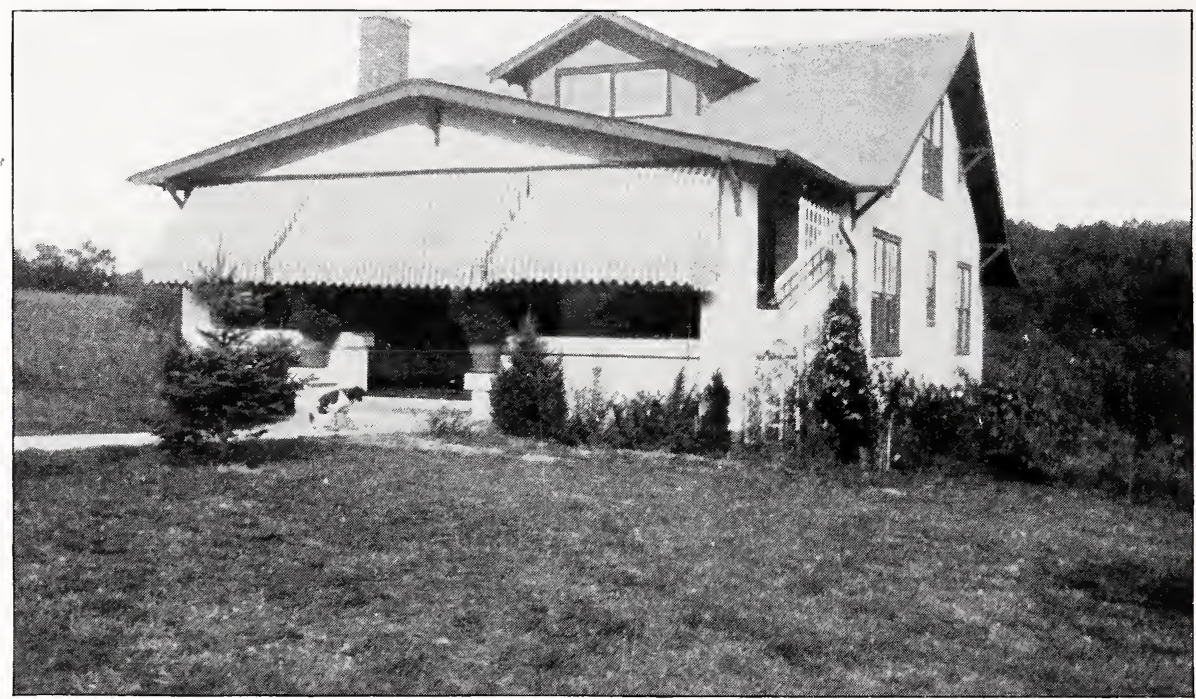

Photo of residence of Dr. H. E. Topping, Staunton, Va., showing just after planting.

\section{SHRUBS, continued:}

VIBURNUM, Opulus (Highbush Cranberry).

Used in clumping, carrying berries through winter.

VIBURNUM, Opulus Sterile (Common Snowball).

Dense bush with profuse white snow-like ball flowers.

VIBURNUM, Plicatum (Japanese Snowball).

Showy white flowers in balls, June. Handsome foliage with purple autumn coloring.

CREPE MYRTLE (Pink, Crepe-like bloom, not hardy North).

IVEIGELA, Amabilis (Rose Veigela).

Light pink in color.

WEIGELA, Candida (White Weigela).

Large, pure-white flowers.

WEIGELA, Floribunda (Crimson IVeigela).

Crimson, June. Free flowering.

WEIGELA, Nana Variegata (Variegated-leaf Weigela).

Pale pink flowers, variegated leaves, dwarf, compact.

WEIGELA, Rosea (Pink Weigela).

Showy pink flowers, freely produced, June. Vigorous grower.

WEIGELA, Eva Rathke (Red Flowering Veigela).

Carmine, June to August. Most floriferous. The most beautiful of the Weigela family. 


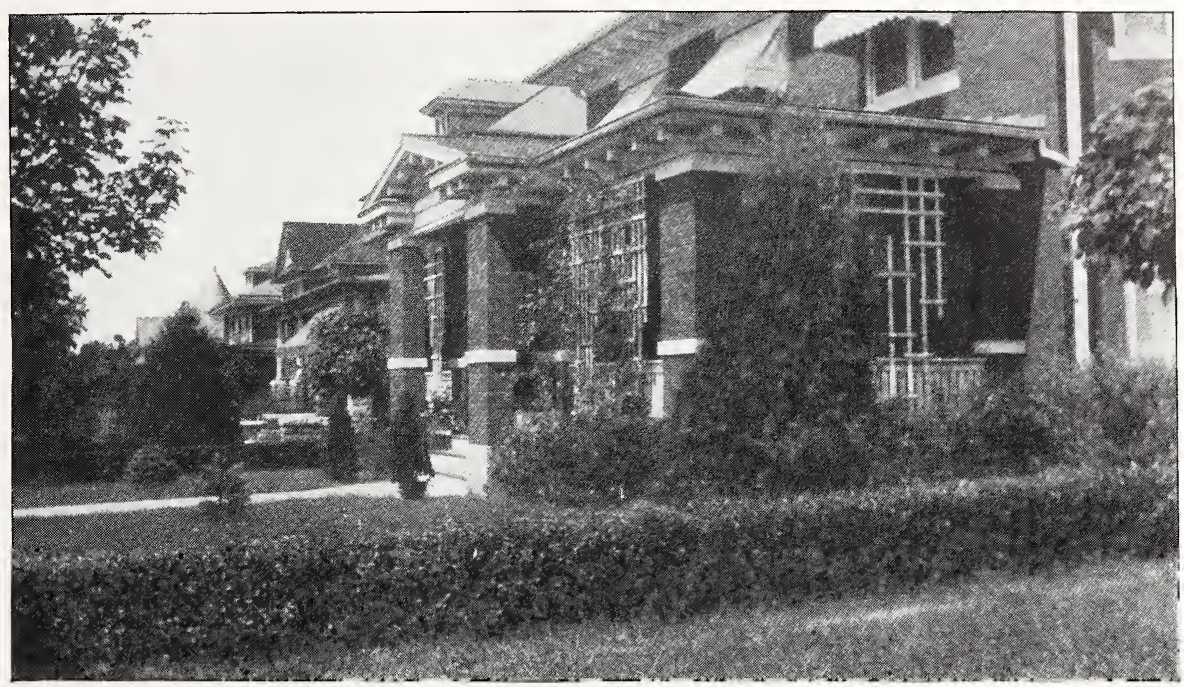

Photo of residence of Mrs. Roy Coffman, Harrisonburg, Va.

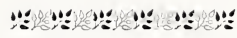

\section{THE SECRETS OF SUCCESSFUL LANDSCAPE GARDENING}

Start out with a definite object in view and plan accordingly.

Avoid straight lines and sharp angles if possible. Graceful curves are more pleasing to the eye.

Plan to leave the center of lawn unobstructed planting the borders with masses of shrubs and trees.

Remember in arranging your shade trees on the lawn, your idea should not be to play checkers with them but to "frame" the house and not hide it. Always leave the center open as it makes the approach more inviting.

For the foundation remember always-height in the corners, immediately in front of pillars and at the bare wall spaces. Under the windows low or medium plants only.

Lawn furniture-that is bird baths, seats, rose arches, sun dials, and wire screens next to evergreens to "keep the pup away," if properly placed make the lawn much more attractive. These little touches help beautify. 


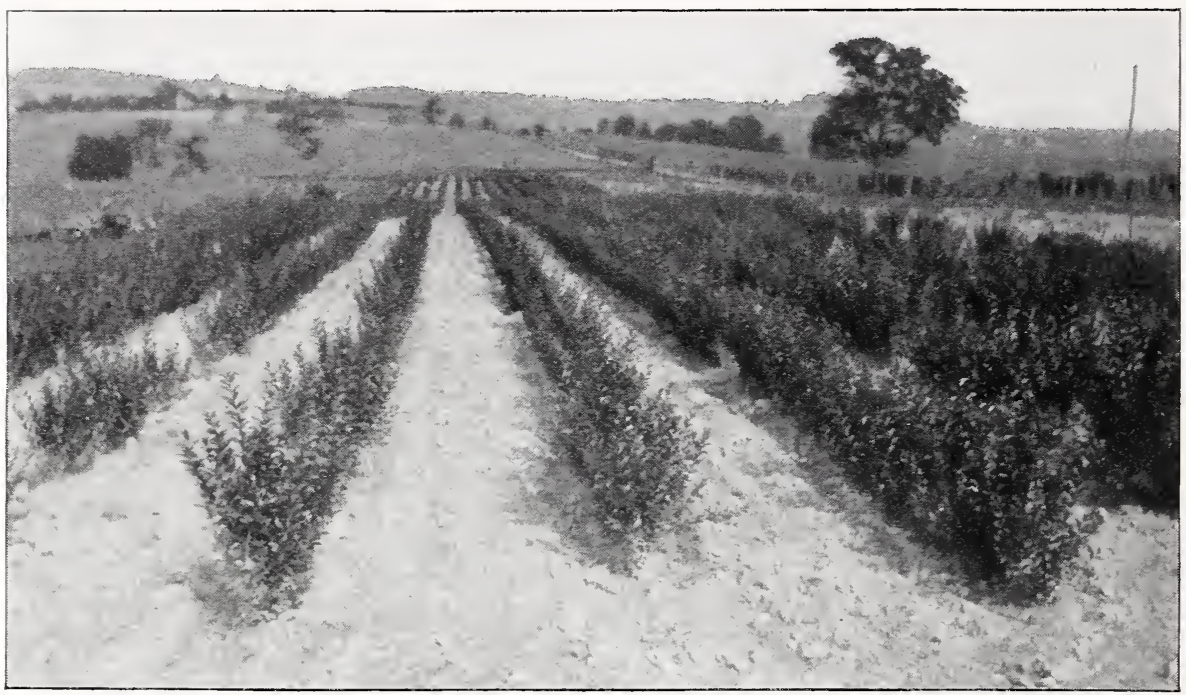

Photo of block in Nursery of twenty-five thousand California Privet, taken August 1, 1925 , before done growing.

\section{HEDGING}

CALIFORNIA PRIVET (Ligustrum Oralifolium).

Very upright, fast grower; best for hedge.

IBOTA PRIVET (Ligustrum Ibolium).

JAPANESE BARBERRY (Berberis Thumbergi).

Green foliage with small yellow bloom in summer, turning scarlet in fall, carrying red berries thru winter. Fine for hedge, individual plant, or in grouping.

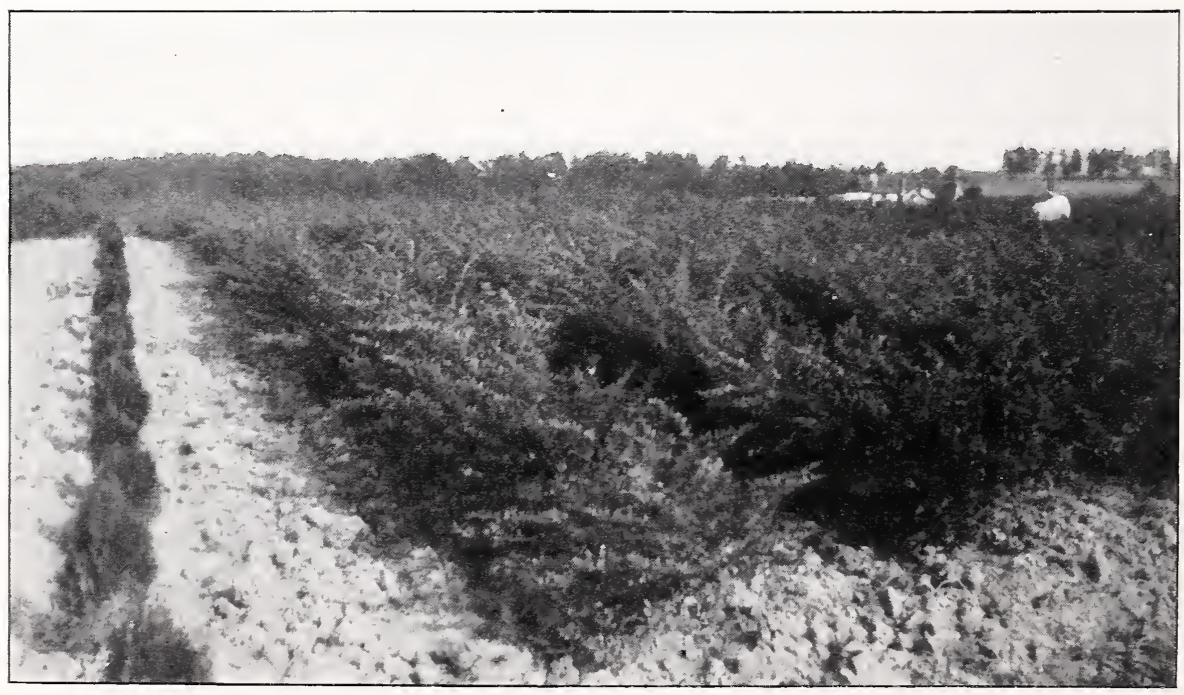

Photo of block in Nursery of four thousand Japanese Barberry, four years old, with row of Berkman's Golden Arborvitae at left. 


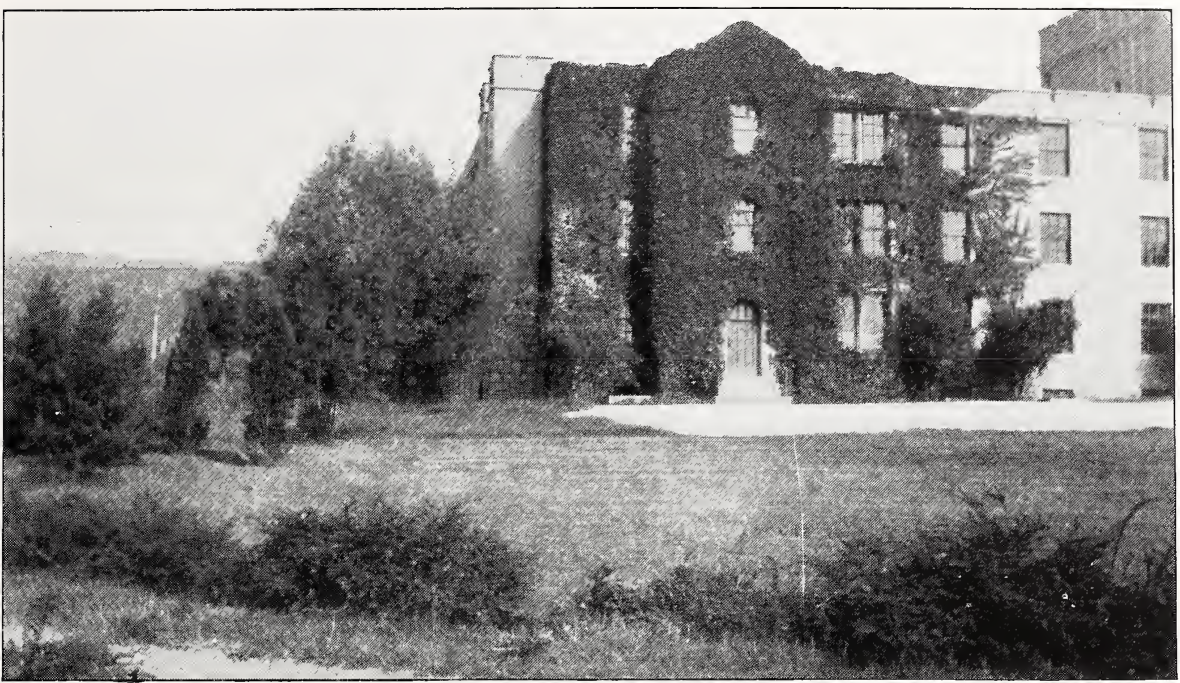

Photo of South corner of Augusta Military Academy, Fort Defiance, Va., showing Hedera Helix, (English Ivy)-Evergreen.

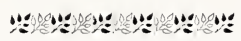

\section{VINES AND CREEPERS}

AMPELOPSIS Quinquefolia (Virginia Creeper).

AMPELOPSIS, Englemanii (Engleman's Ivy).

AMPELOPSIS, Veitchei (Boston Ivy).

HEDERA HELIX (English Ivy). Evergreen.

CLEMATIS Paniculata (Sweet Autumn Clematis).

LONICERA HALLIANA (Hall's Japanese Honeysuckle).

WISTERIA FRUTESCENS (American Wisteria).

WISTERIA SINENSIS (Chinese Wisteria).

VINCA MYRTLE, or Periwinkle.

An evergreen ground-cover.

JAPANESE SPURGE (Pachysandra Terminalis).

An evergreen broad-leaved vine, six inches in height. Very hardy. 


\section{ROSES}

We grow very few roses, only Climbing Tea and Hardy Climbers in small variety.

CLIMBING AMERICAN BEAUTY.

Red flowers like Bush Rose of that name.

CRIMSON RAMBLER-Deep Crimson.

DOROTHY PERKINS-Shell Pink.

IVHITE DOROTHY PERKINS.

Similar to Dorothy Perkins, but white.

EXCELSA (Red Dorothy Perkins).--Clear Scarlet.

FLOWERS OF FAIRFIELD-Red.

PAUL'S GOLDFINCH-Yellow.

\section{DWARF POLYANTHA, OR "BABY" ROSES}

RED BABY RAMBLER

WHITE BABY RAMBLER

\section{HARDY PERENNIAL FLOWERS}

CHRYSANTHEMUMS in colors-red, white, pink and yellow. HOLLYHOCKS.

IRIS, in variety. 


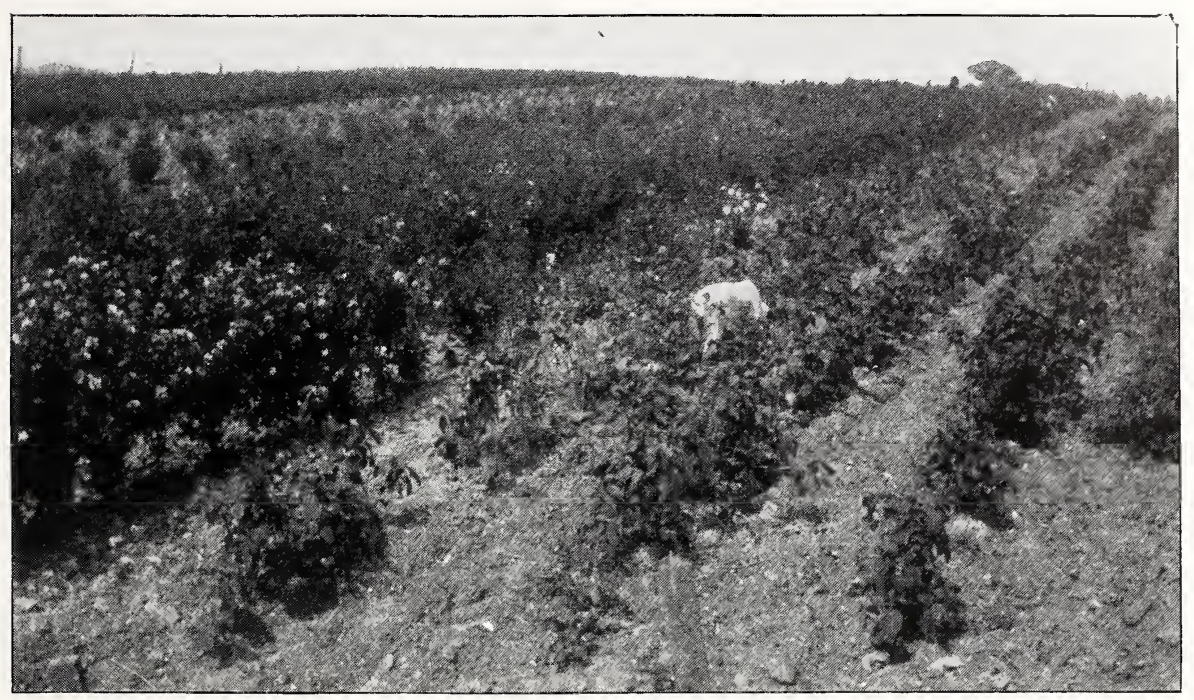

Photo in Nursery of Hydrangea P. G. and Altheas

ำ

\section{CARE OF SHRUBS}

Shrubs should be planted just like an Evergreen or Shade, of course giving plenty of plant food and moisture.

After each year's growth in March of each year, all tall growing Shrubs should be severely pruned back, at least onethird last year's growth, so the plant will throw out more young shoots from the root, thereby giving a heavier and more floiferous bloom the following years-the more wood the root of a plant has to support, the less profusion of flowers it will produce. 


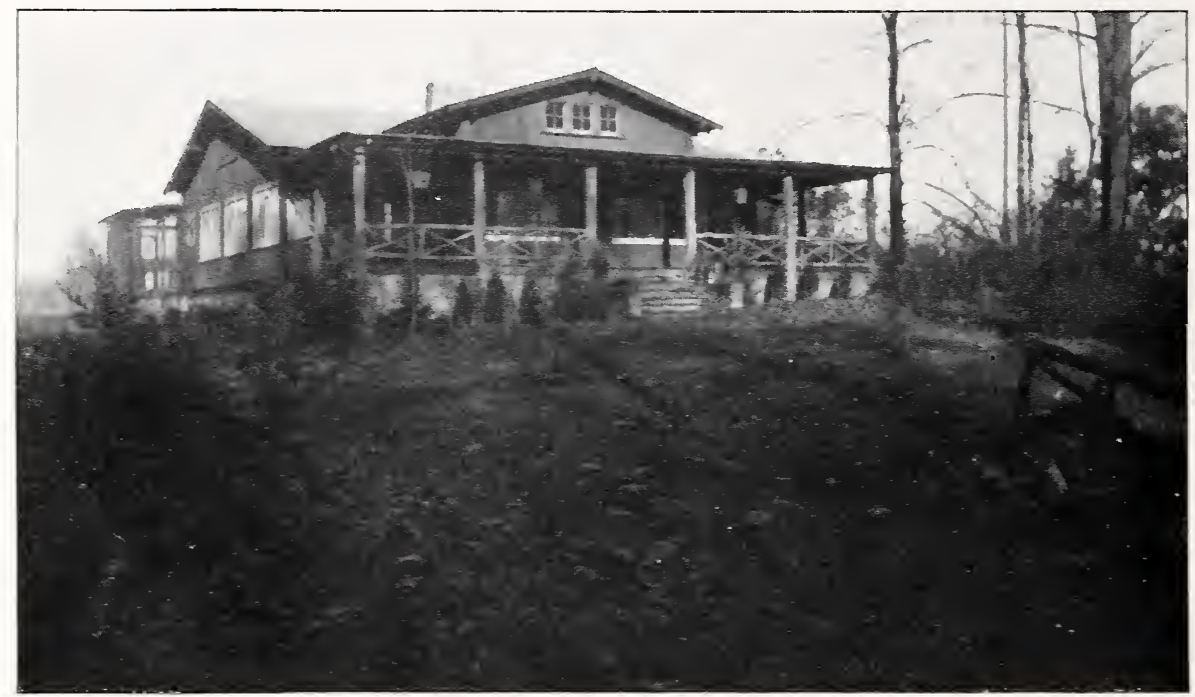

Photo of Mrs. I. L. Witz's Bungalow on North River at Van Ike, taken Dec. 1, 1925, after foliage all off of trees.

\section{$\because \because \because \because \because \because \because$}

This is the day of specialists and we flatter ourselves by saring that we think we can grow the best shrubs and erergreens for our local clientele who can get them just after digging, and plants that you know will grow and give immediate effect. If not, we are here and not there. You can find us.

Plants grown near the place of the last planting will. most naturally, be acclimated and best suited to the local soil conditions.

Also they need not be out of the ground too long to be dried up and unfit for planting: 


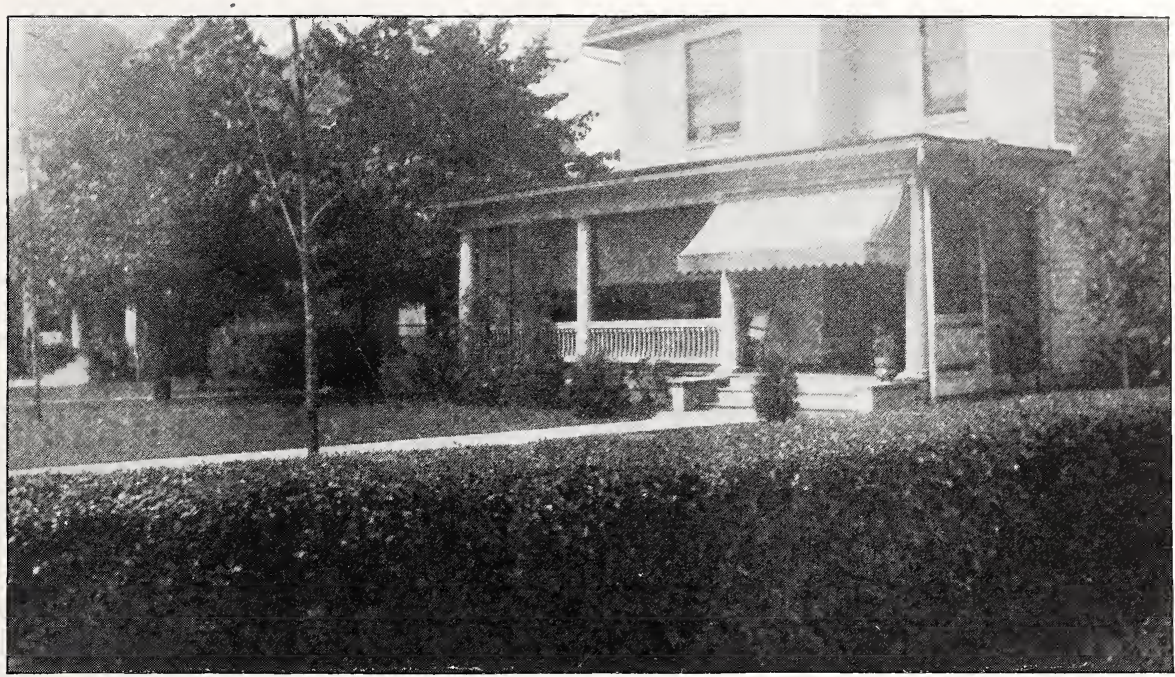

Photo of residence of Dr. C. E. Nicholas, Harrisonburg, Va., showing California Privet hedge in foreground.

$$
\text { 世: }
$$

\section{PRICES ON SHADE TREES :}

Norway Maple, 7 to $8 \mathrm{ft} ., \$ 2.00 ; 10$ to $12 \mathrm{ft}$., $\$ 4.00 ; 12$ to $15 \mathrm{ft}$., $\$ 6.00$ Silver Maple, 7 to $8 \mathrm{ft}$., $\$ 1.00 ; 10$ to $12 \mathrm{ft}$., $\$ 2.00 ; 12$ to $15 \mathrm{ft}$. $\$ 3.00$ Sugar Maple, same heights and prices as the Norway.

Biloba Ginkgo, 8 to $10 \mathrm{ft.,} \$ 5.00$

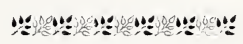

\section{HOW TO PLANT SHADE TREES}

When practicable, holes should be dvnamited for the larger trees; do not put any manure in holes, use Raw Bone Meal while planting and well-rotted horse stable manure on top. Heavy trees should be staked to keep wind from whipping about. 
A UGUSTA NURSERIES

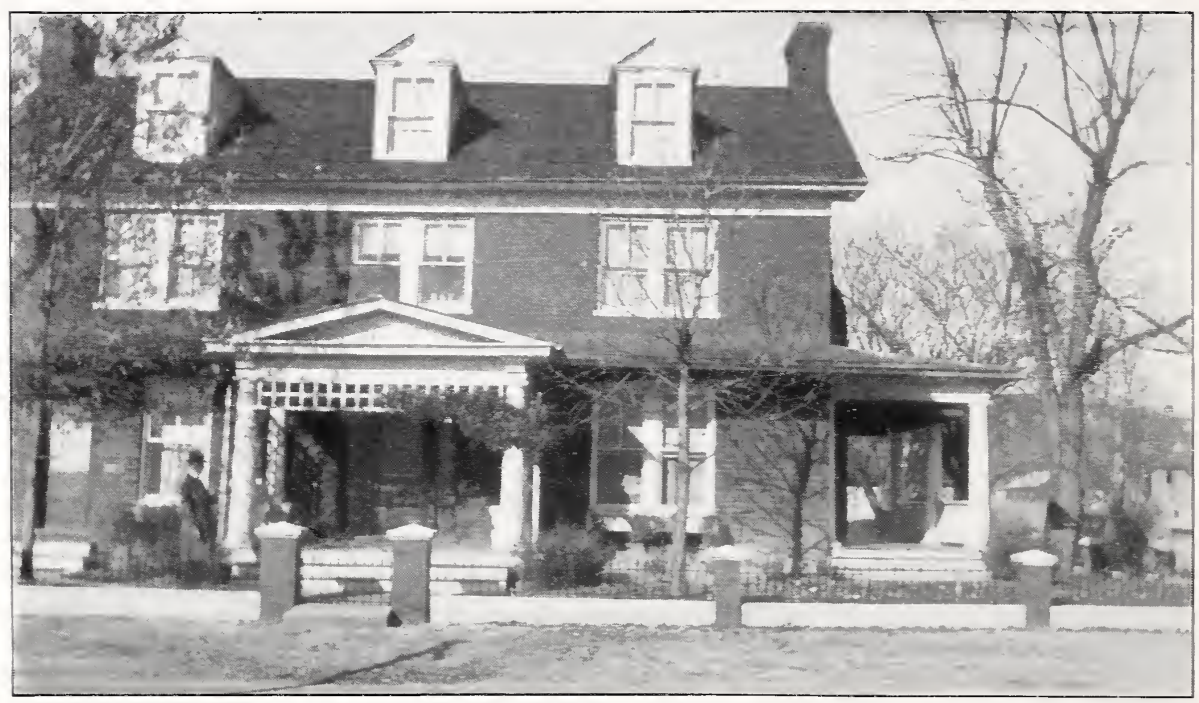

Photo of residence of Dr. F. H. Crawford, Mt. Sidney, Ta.

$\because \because \because \because \because \because \%$

\section{PRICES OF EVERGREENS}

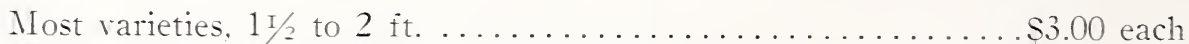

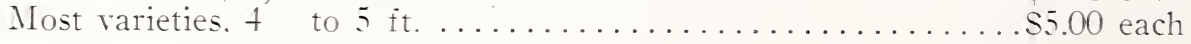

Except Pfitzeranan and Sabina Juniper

$1 \times 1$ ft.. $\$ 3.00 ; 3 \times 3$ ft.. $\$ 5.00$ each

Koster's Blue Spruce, 2 ft.. \$5.00: 4 to 5 ft.. $\$ 15.00$

Phone Call.

Letter or Card

Will Bring Ls

to See Iour

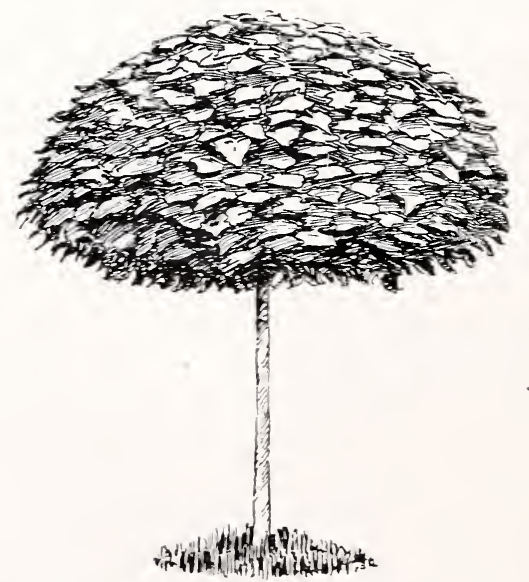

Price of Lmbrella

Trees

1 year head $\$ 1.50$

5 rear head $\$ 5.00$

Catalpa Bungeii (or Umbrella Tree). 


\section{SHADE TREES, EVERGREENS AND SHRUBBERY SPECIALISTS}

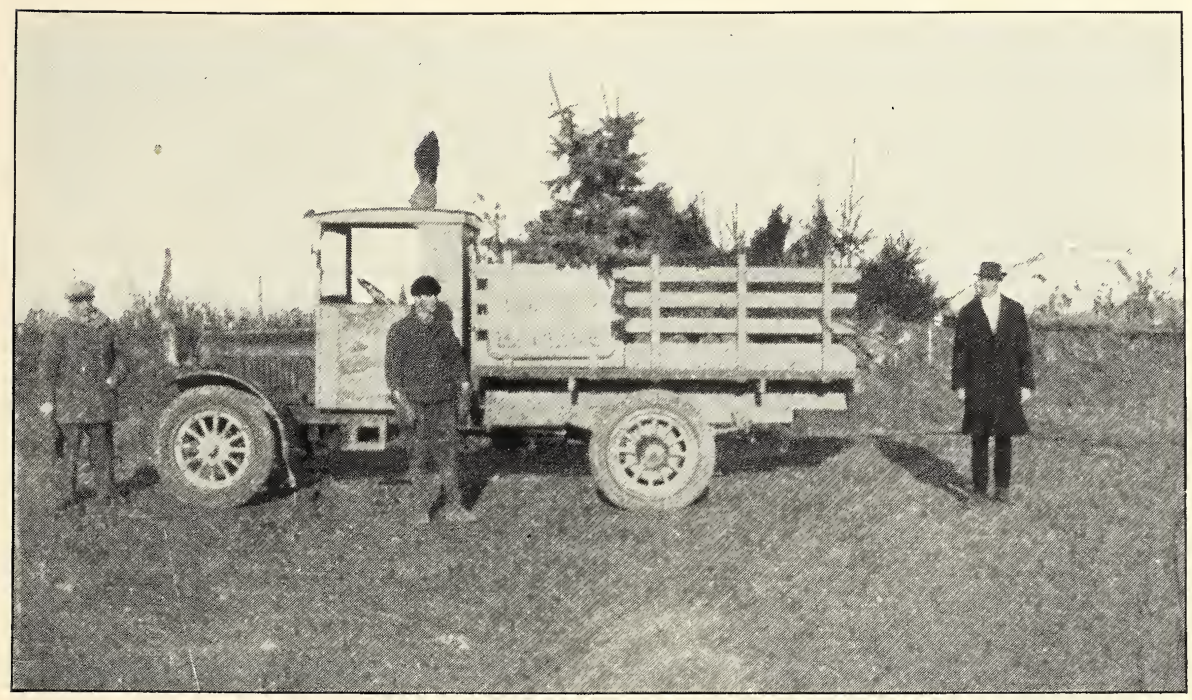

This is one of the truck loads of Evergreens and Shrubs being hauled to Court Manor, New Market, Va., Mr. W. S. Kilmer's race-horse breeding farm, one of the largest in the South. (See pictures of residence and different scenes on farm, pages 2 and 3 ). 


\section{Augusta Nurseries}

N. L. Shreckhise, Mgr.

Mount Sidney, Virginia

Phone thru Weyers Cave, 23-F-12

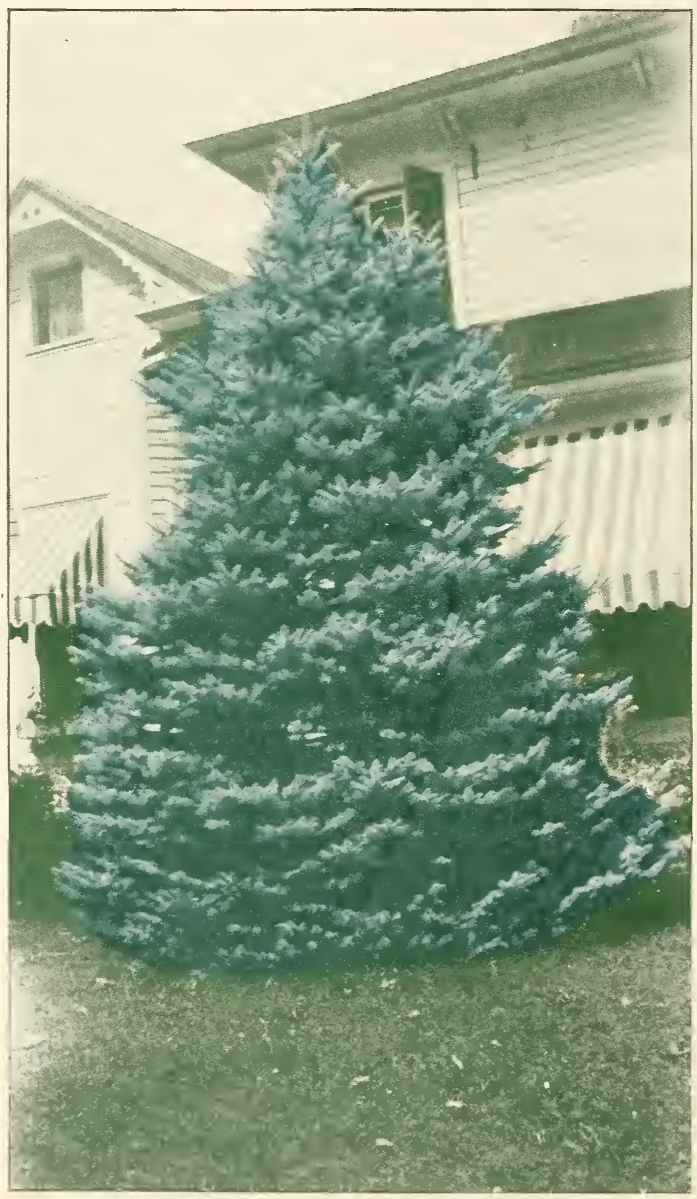

A Specimen of Koster's Grafted Blue Spruce at the residence of Mrs. R. T. Lambeth, Fort Defiance, Va. 